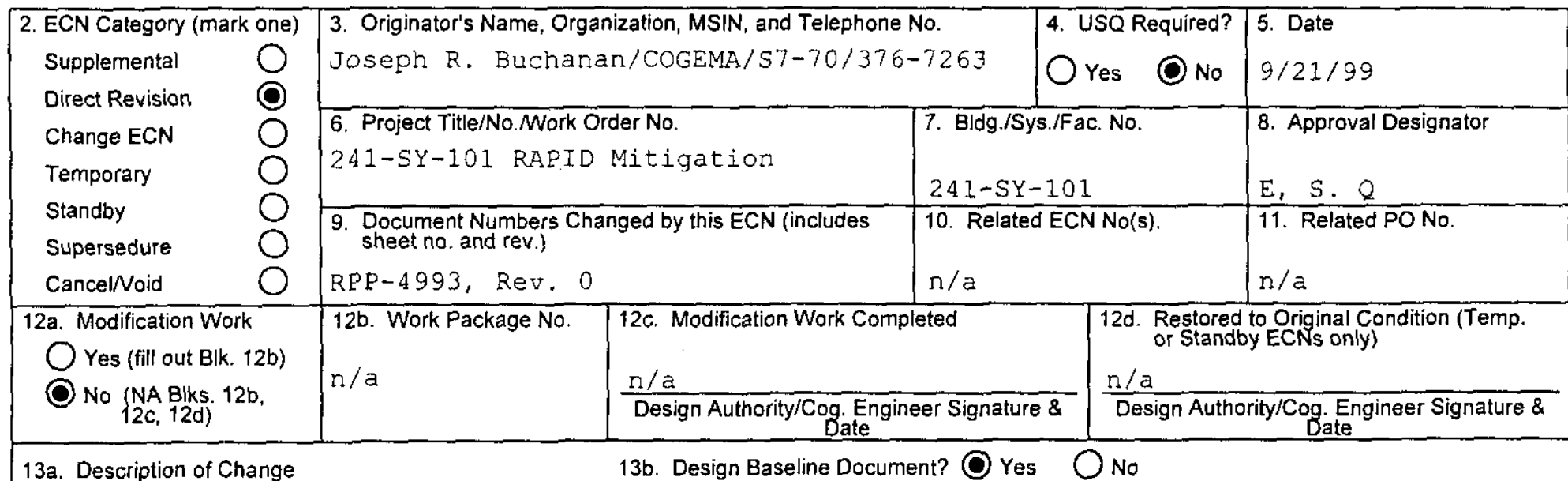

Complete rewrite of subject document - 6430.1A Compliance Matrix for 241-SY-101 Surface Level Rise Remediation Project - see attached continuation sheets.

Information updated and added to in order to demonstrate compliance of the entire RAPID Mitigation System with DOE Order 6430.1A. No USQ screening is necessary for this change per HNE-IP-9842, Vol. IV, Sec. 5.4, Rev. 11b.

15. Distribution (include name, MSIN, and no. of copies)

W.J. Poweli $/ 57-70 / 1$

M. F. Erhart/S7-70/1

R.W. Reed/T4-07/I

M.L. MCElroy/S7-07/1

C.D. Jackson/S7-34/1

D.L. Dyekman/R1-51/1

C.E. Hanson/S7-70/1

R.L. Schlosser/R1-56/1

J.R. Buchanan/S7-70/1
M.H. Brown/T4-07/1

V.K. Izaguirre/S7-70/5

G.A. Leshikar/s0-08/1

J.L. Wilk/S7-70/1

R.E. Merriman/E6-27/1

G.A. Barnes/57-70/1

K.S. Witwer $/ \$ 7-70 / 1$

J.P. King/S7-70/1

R.E. Raymond/S7-70/1

\section{RELEASE STAMP}

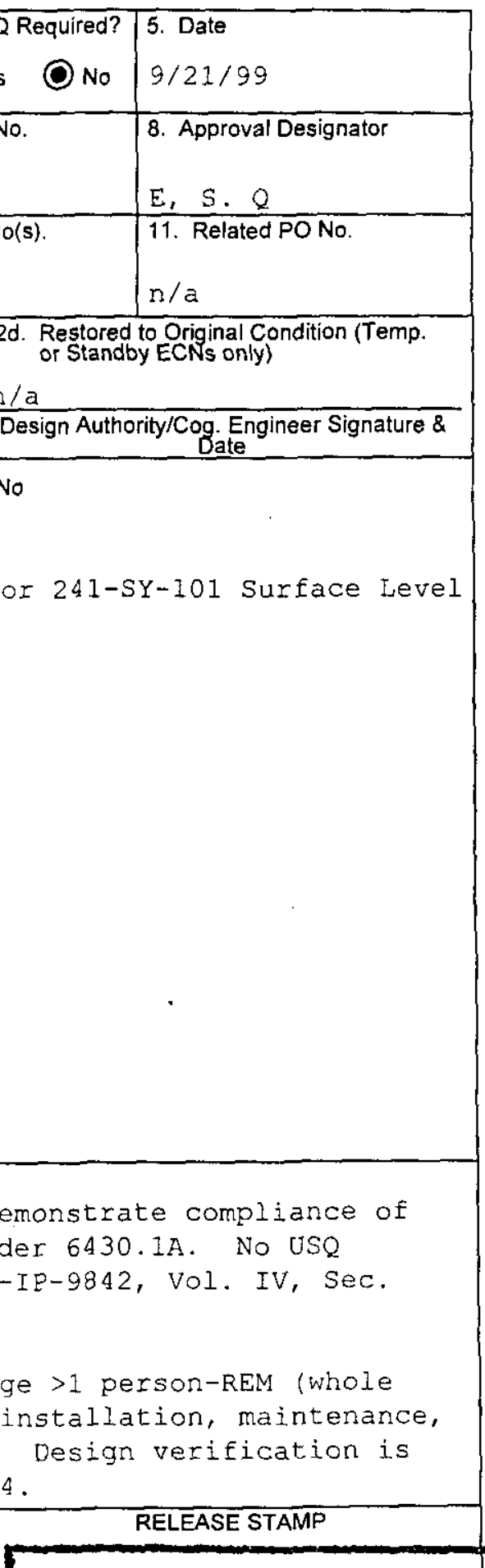




\section{ENGINEERING CHANGE NOTICE}

16. Design Verification 1 17. Cost Impact

Required

Yes

O No
17. Cost Impact
ENGINEERING

Additional $\bigcirc \$ n / a$

Savings $\bigcirc \$$
Page 2 of 2 CONSTRUCTION

Additional $\bigcirc \$ n / a$

Savings $\bigcirc \$$
1. ECN (use no. from pg. 1)

655884

18. Schedule Impact (days)

Improvement

n $/ a$

Delay

O

19. Change Impact Review: Indicate the related documents (other than the engineering documents identified on Side 1) that will be affected by the change described in Block 13. Enter the affected document number in Block 20.

$\begin{array}{llll}\text { SDD/DD } & \square & \text { Seismic/Stress Analysis } & \square \\ \text { Functional Design Criteria } & \square & \text { Stress/Design Report } & \square \\ \text { Operating Specification } & \square & \text { Interface Control Drawing } & \square \\ \text { Criticality Specification } & \square & \text { Calibration Procedure } & \square \\ \text { Conceptual Design Report } & \square & \text { Installation Procedure } & \square \\ \text { Equipment Spec. } & \square & \text { Maintenance Procedure } & \square \\ \text { Const. Spec. } & \square & \text { Engineering Procedure } & \square \\ \text { Procurement Spec. } & \square & \text { Operating Instruction } & \square \\ \text { Vendor Information } & \square & \text { Operating Procedure } & \square \\ \text { OM Manual } & \square & \text { Operational Safety Requirement } & \square \\ \text { FSAR/SAR } & \square & \text { IEFD Drawing } & \square \\ \text { Safety Equipment List } & \square & \text { Cell Arrangement Drawing } & \square \\ \text { Radiation Work Permit } & \square & \text { Essential Material Specification } & \square \\ \text { Environmental Impact Statement } & \square & \text { Fac. Proc. Samp. Schedule } & \square \\ \text { Environmental Report } & \square & \text { Inspection Plan } & \square \\ \text { Environmental Permit } & \square & \text { Inventory Adjustment Request } & \square\end{array}$

Tank Calibration Manual Health Physics Procedure Spares Multiple Unit Listing Test Procedures/Specification Component Index ASME Coded Item Human Factor Consideration Computer Software

Electric Circuit Schedule ICRS Procedure

Process Control Manual/Plan Process Flow Chart

Purchase Requisition Tickler File

$\mathrm{n} / \mathrm{a}$

20. Other Affected Documents: (NOTE: Documents listed below will not be revised by this ECN.) Signatures below indicate that the signing organization has been notified of other affected documents listed below.

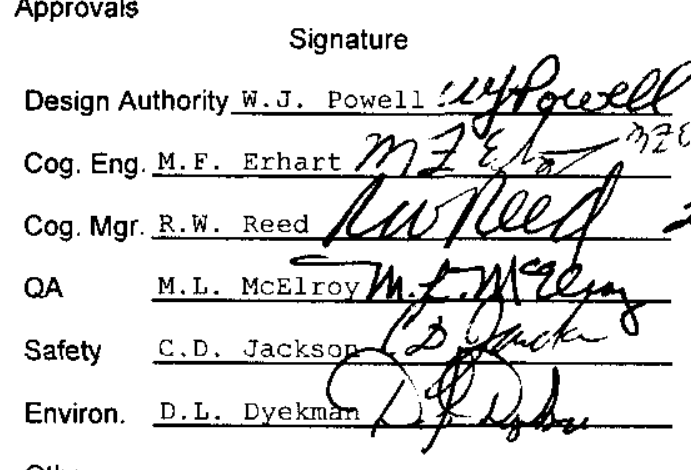

Other

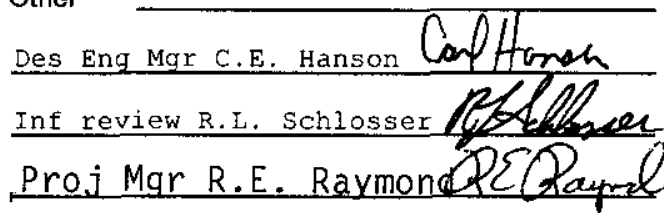

$$
\text { Date }
$$

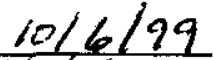
(1) $9124 / 99$
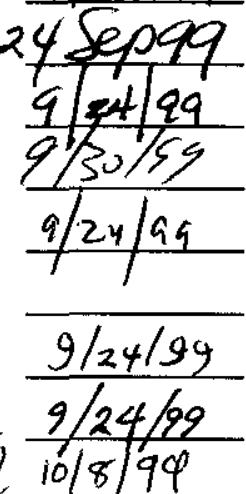

Proj Mgr R.E. Raymond RE Ray

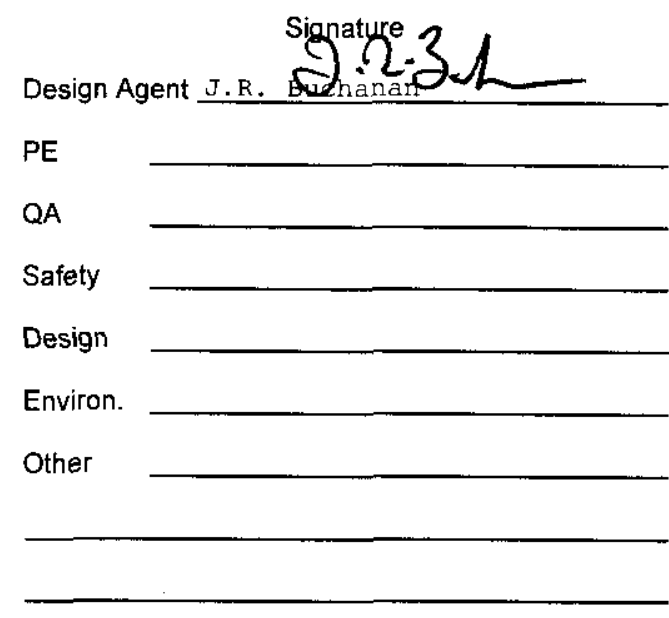

\section{DEPARTMENT OF ENERGY}

Signature or a Control Number that tracks the Approval Signature

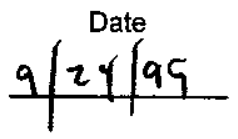

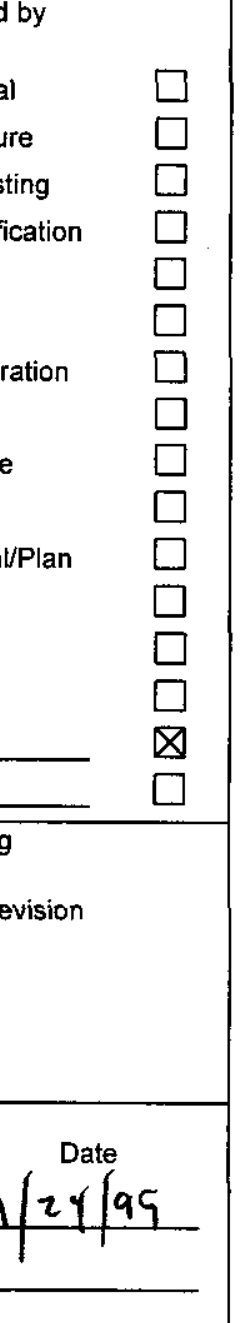




\subsection{A Compliance Matrix for 241-SY-101 Surface Level Rise Remediation Project}

M. F. Erhart

Lockheed Martin Hanford Company

Richland, WA 99352

U.S. Department of Energy Contract DE-AC06-96RL13200

EDT/ECN: 627412

UC: 2030

Org Code: 79000

B\&R Code: EW3120071

Charge Code: HN920201

Total Pages: $40,42 \quad 47+5$

Key Words:

Jes Jno

16169910199

RAPID, transfer; SY Farm, 241-SY-101, SY-101 pump pit, PPP

Abstract:

This document shows compliance with DOE order 6430.1A of the 241-SY-101 RAPID Mitigation system.

TRADEMARK DISCLAIMER. Reference herein to any specific commercial product, process, or service by trade name, trademark, manufacturer, or otherwise, does not necessarily constitute or imply its endorsement, recommendation, or favoring by the United States Government or any agency thereof or its contractors or subcontractors.

Printed in the United States of America. To obtain copies of this document, contact: Document Control Services, P.O. Box 950, Mailstop H6-08, Richland WA 99352, Phone (509) 372-2420; Fax (509) 376-4989.

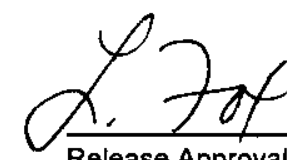

Release Approval
OCr 081999

Date

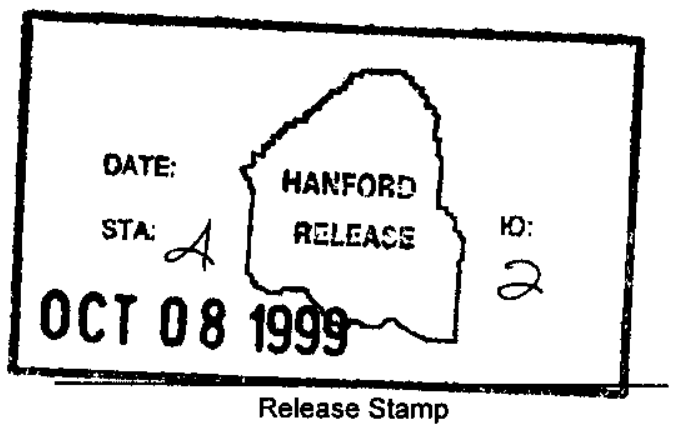




\section{RECORD OF REVISION}

(1) Document Number

RPP -4993

(2) Title

6430.1A Compliance Matrix for 241-Sy-101 Surface Level Rise Remediation Project

Change Control Record

(3) Revision

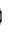

1 RS
(4) Description of Change - Replace, Add, and Delete Pages

(7)

ORIGINAL RELEASE EDT $627412,8 / 13 / 99$

ECN 655884

Authorized for Release

\begin{tabular}{l|ll} 
(5) Cog. Engr. & (6) Cog. Mgr. Date
\end{tabular}

\begin{tabular}{l|l} 
SEE EDT & SEE EDT
\end{tabular}

SEE ECN JRB SEE ECN JRS

Page 1 


\subsection{BACKGROUND}

Tank 241-SY-101 (SY-101) has recently exhibited a steady waste surface level growth. A path forward to mitigate the SY-101 surface level growth issue has been developed. The project has been directed to install the necessary equipment to transfer $380-570 \mathrm{~m} 3$ (100,000-150,000 gallons) of waste from SY-101 to SY-102 before the waste elevation reaches the region of the tank where the transition from a double to a single shell tank occurs.

\subsection{PURPOSE}

The purpose of this document is to record the design attributes of the RAPID Mitigation System which fulfill the pertinent requirements specified in DOE Order 6430.1A General Design Criteria. Those pertinent Order requirements which are not met by the project at the time of the release of this document are recorded and noted as open items in Section 4.0 - Conclusions.

\subsection{ANALYSIS}

An initial review of DOE Order 6430.1A was performed and selected sections of the specified design criteria were identified as pertaining to the SY-101 RAPID Mitigation System project. General design criteria which are crucial to the safe and effective operation of the RAPID System were selected for demonstration of compliance and are derived from the following sections of the Order:

\section{Division $1-$ General Requirements}

Section 0109 - Reference Standards and Guides

Section 0110 - Architectural and Special Design Requirements

Section 0111 - Structural Design Requirements

Section 0140 - Quality Assurance

\section{Dixision $2-$ Site and Civil Engineering}

Section 0200 - Site Development

Section 0201 - Subsurface Investigations

Section 0203 - Utilities Within Easements or Corridors

Section 0205 - Demolition, Decontamination, and Decommissioning

Section 0220-Earthwork

Section 0235 - Building Foundations

\section{Division 3 - Concrete}

Section 0301 - General Requirements

Section 0320 - Concrete Reinforcement

Section 0340 - Precast Concrete 


\subsection{ANALYSIS (cont'd)}

Division 5-Metals

Section 0512 - Structural Steel

Section 0532 - Metal Fastening

Division 9-Finishes

Section 0900 - General

Division 11 - Equipment

Section 1161-Enclosures

Division 13 - Special Facilities

Section 1300 - General Requirements

Section 1323 - Radioactive Liquid Waste Facilities

Division 15-Mechanical

Section 1525 - Mechanical Insulation

Section 1530 - Fire Protection

Division 16-Electrical

Section 1605 - Basic Electrical Material and Methods

Section 1630 - Exterior Electrical Utility Service

Section 1639-Grounding

Section 1640-Interior Electrical Systems

Section 1660 - Special Systems

Section 1671 - Interior Communications and Alarm Systems

The matrix contained on the following pages records specific requirements contained in these sections which are pertinent to the SY-101 RAPID Mitigation System. A citation is provided which specifies the design document and attribute which fulfills each criterion's requirement. 


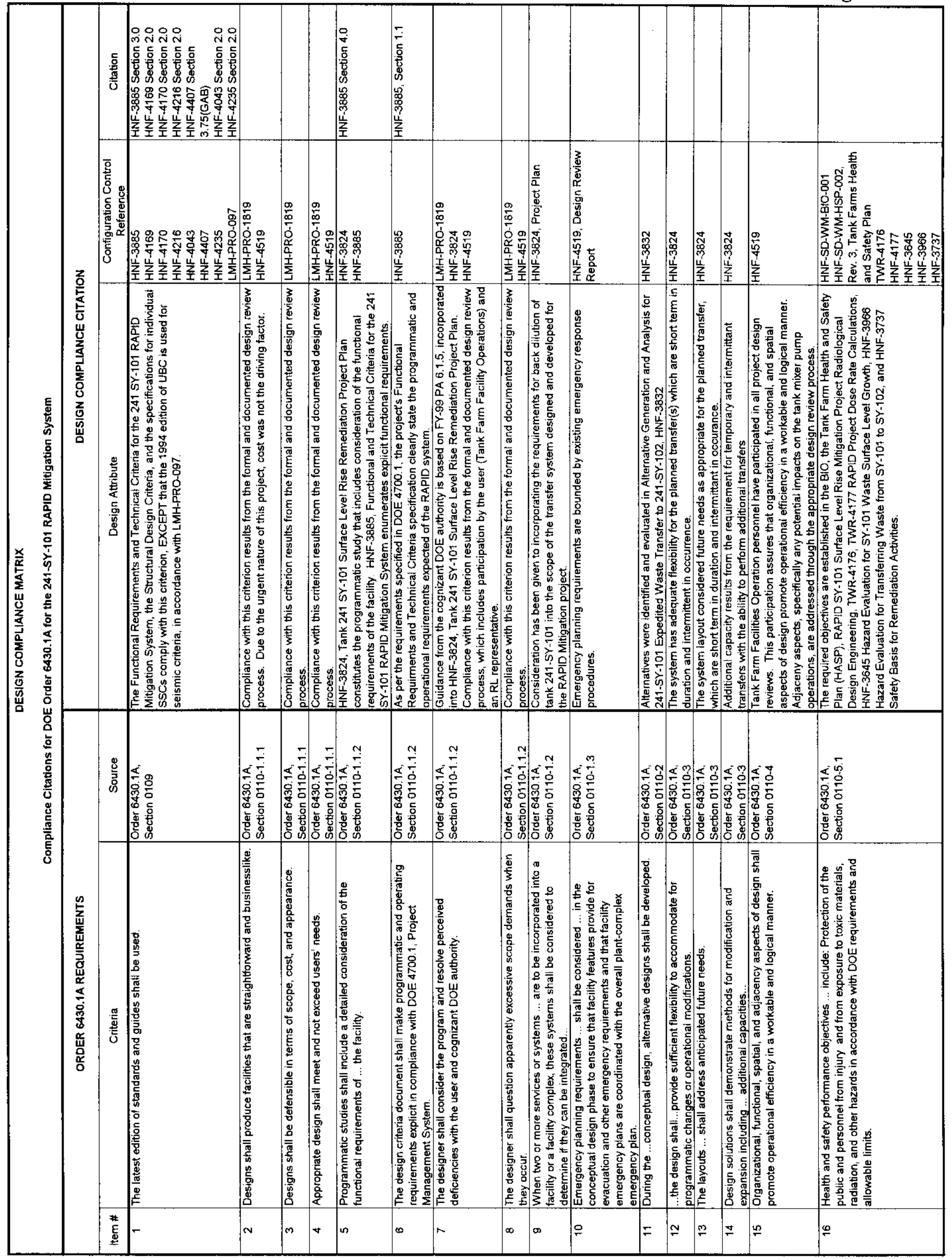


RPP-4993, Rev 1

Page 5 of 44

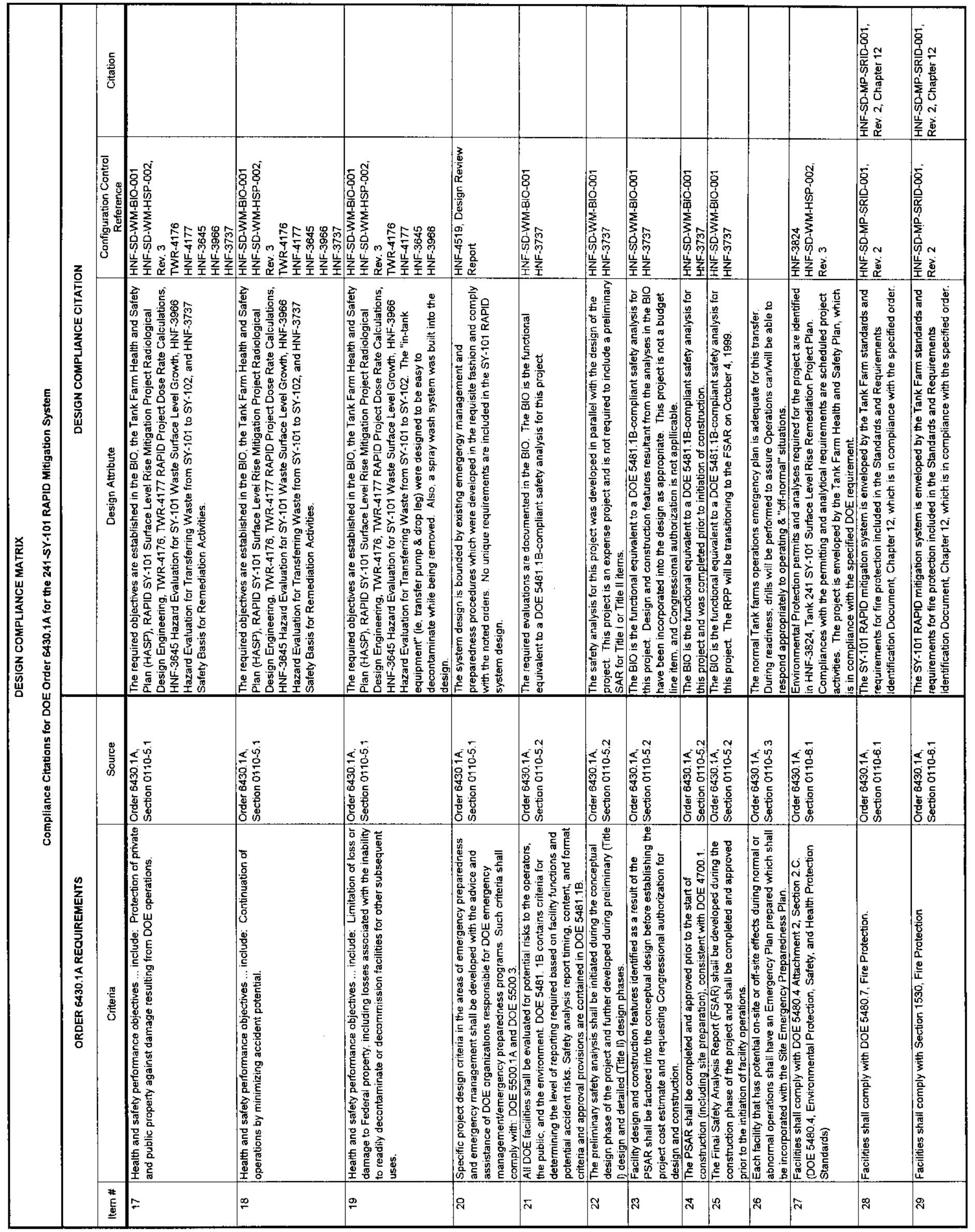




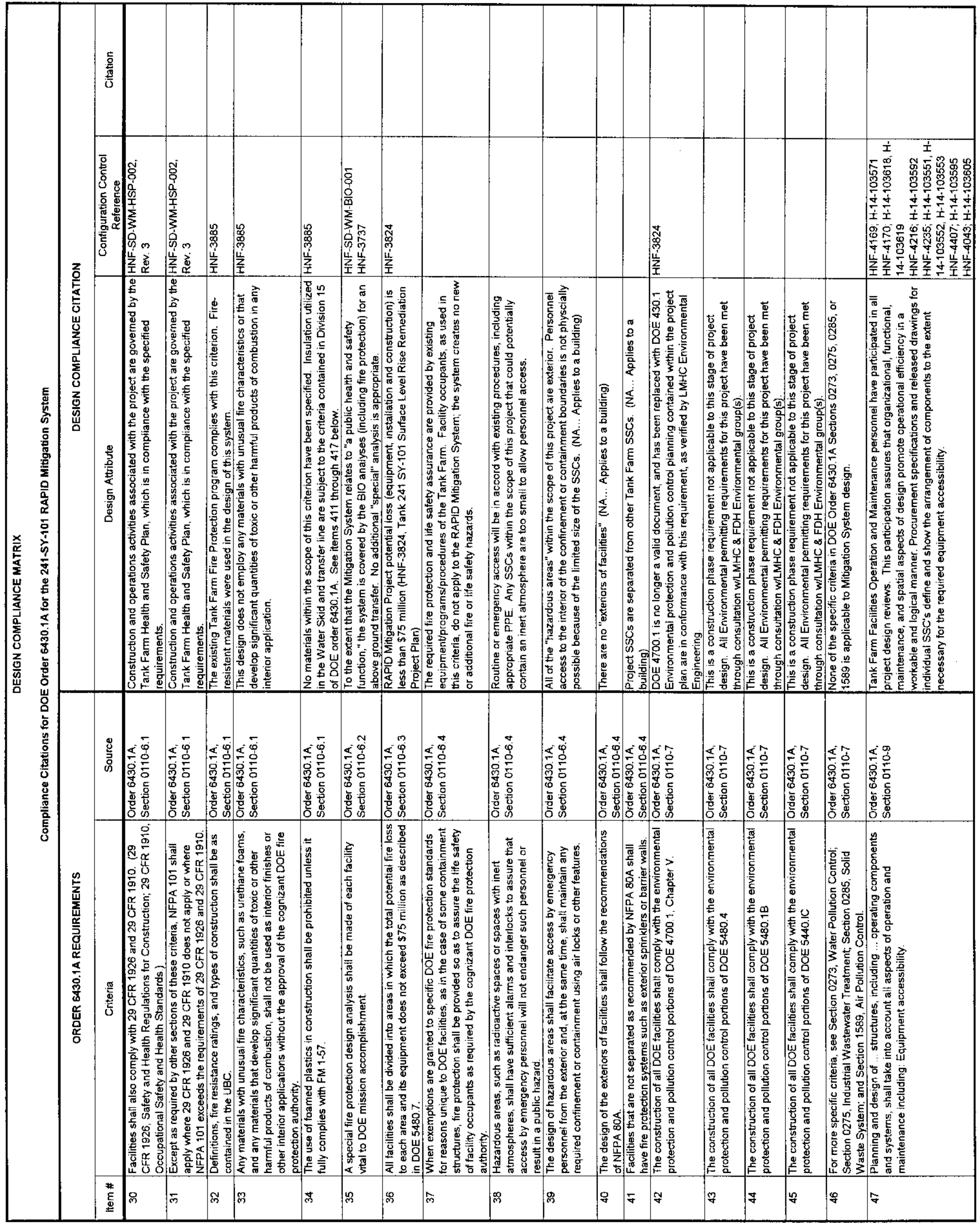




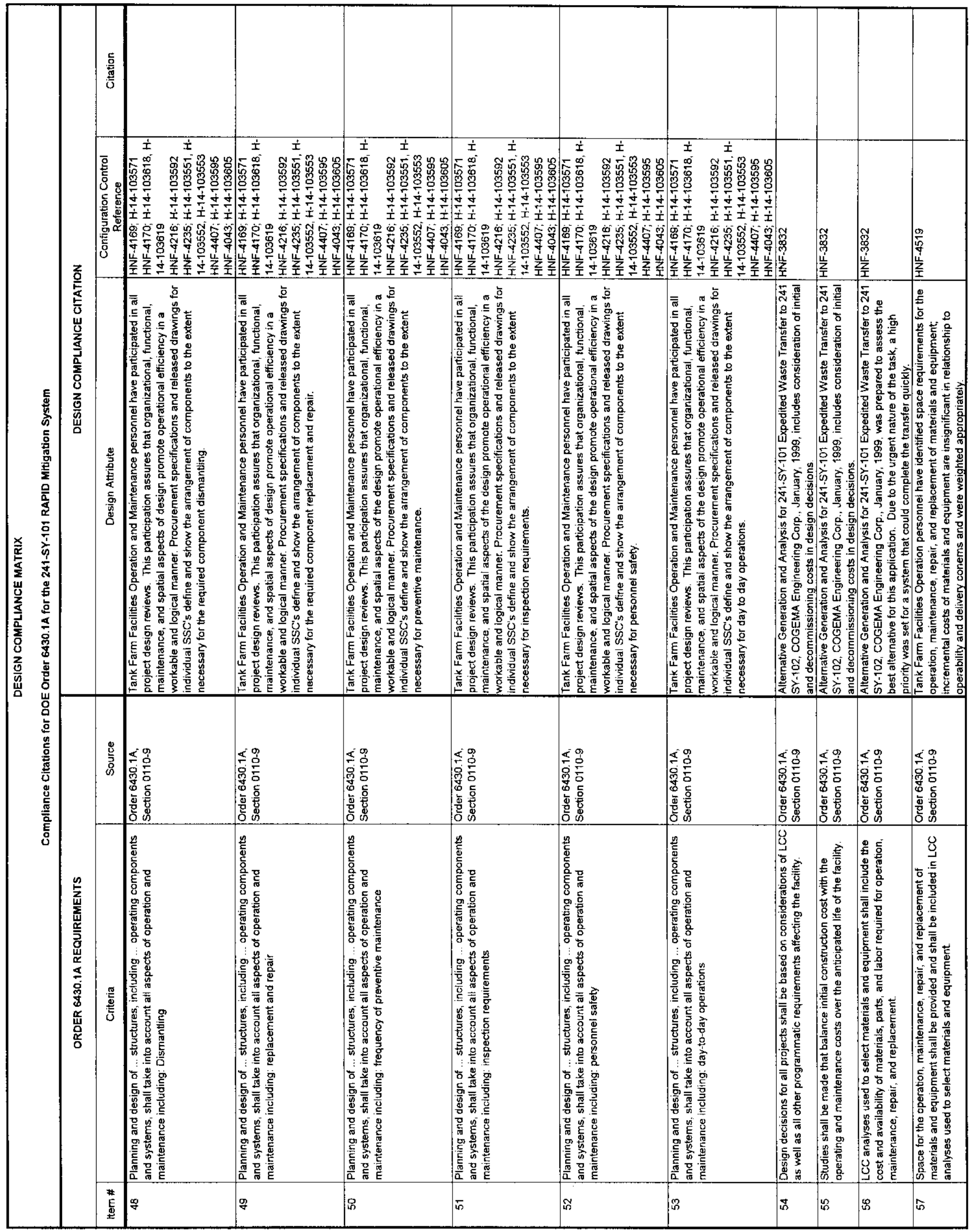




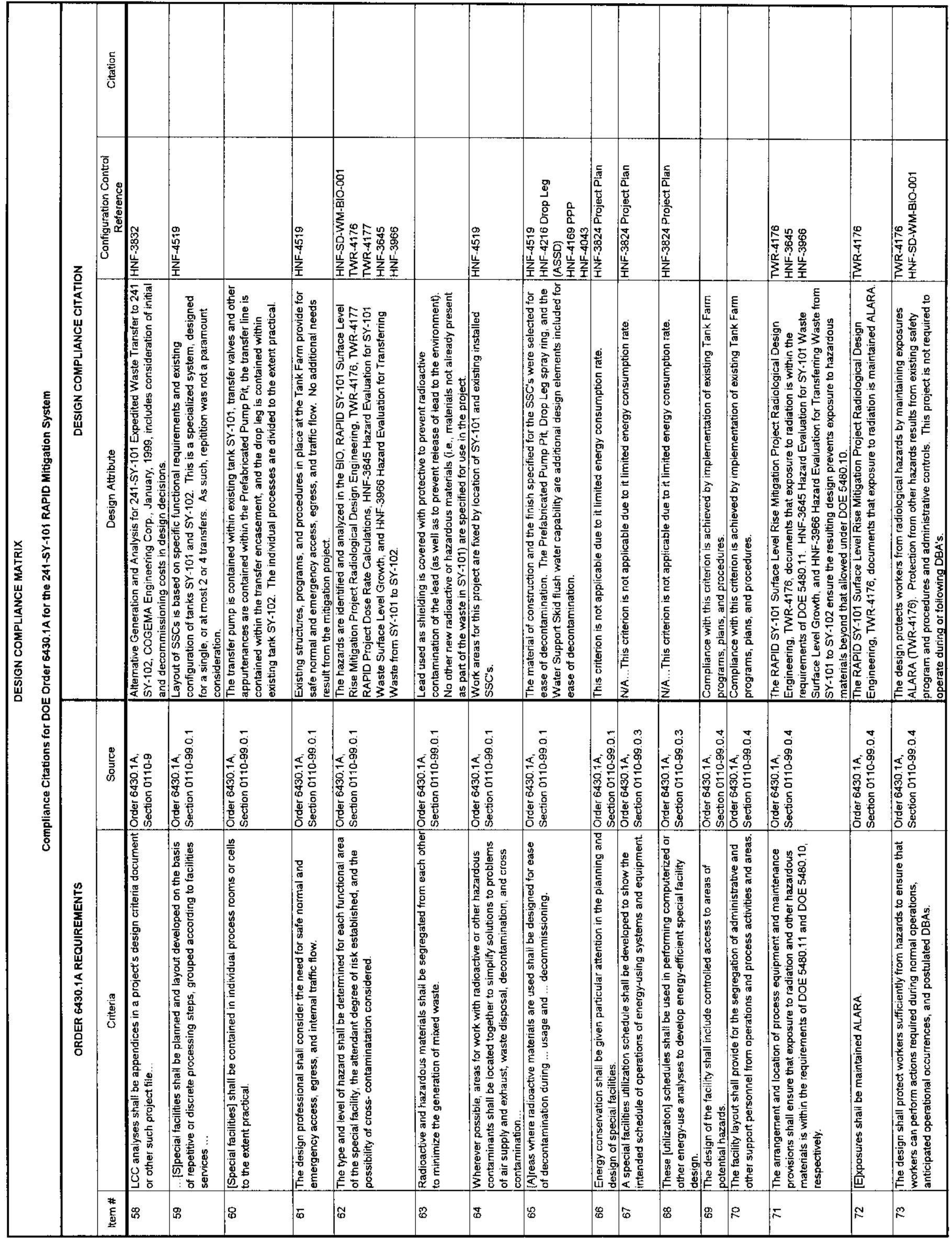




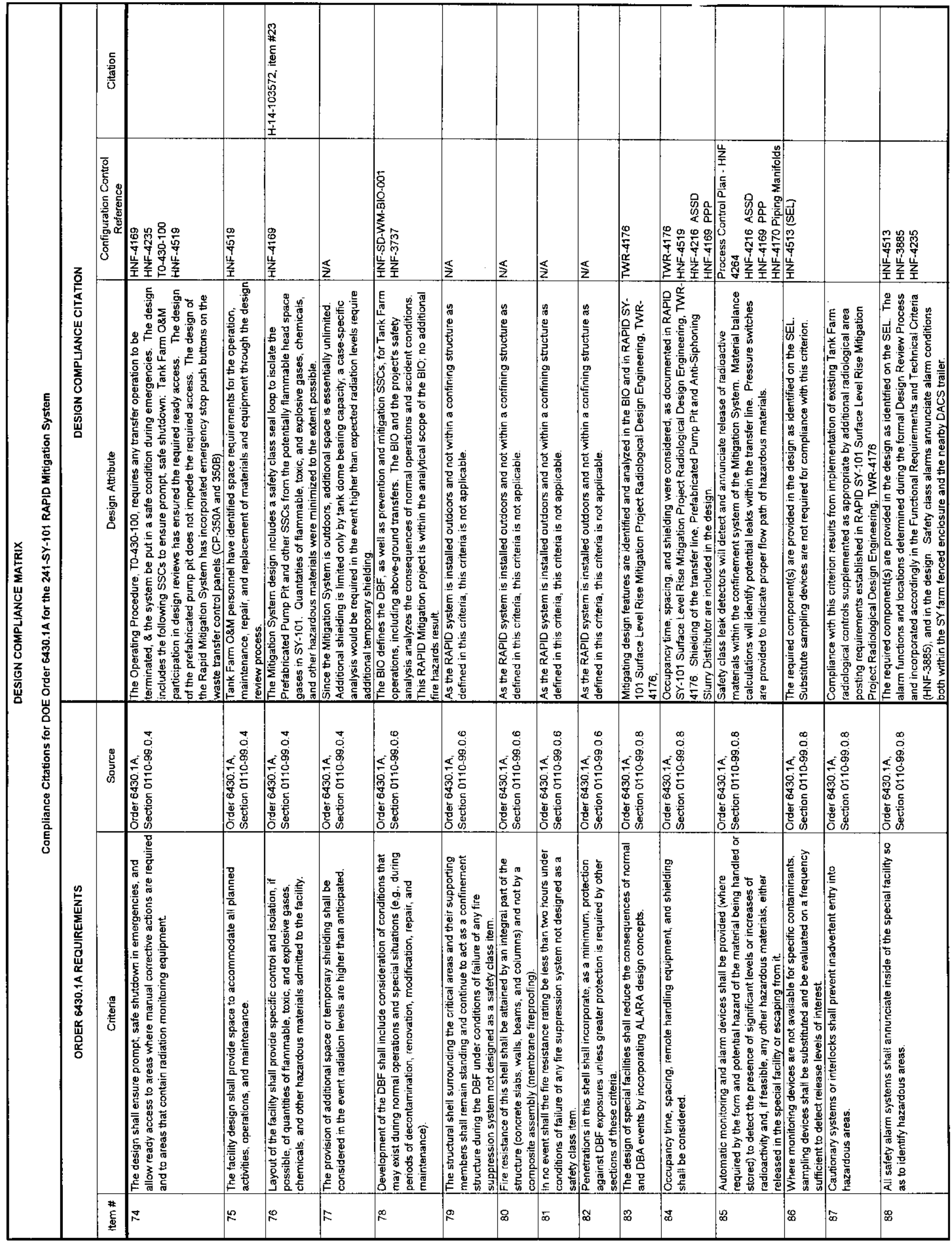




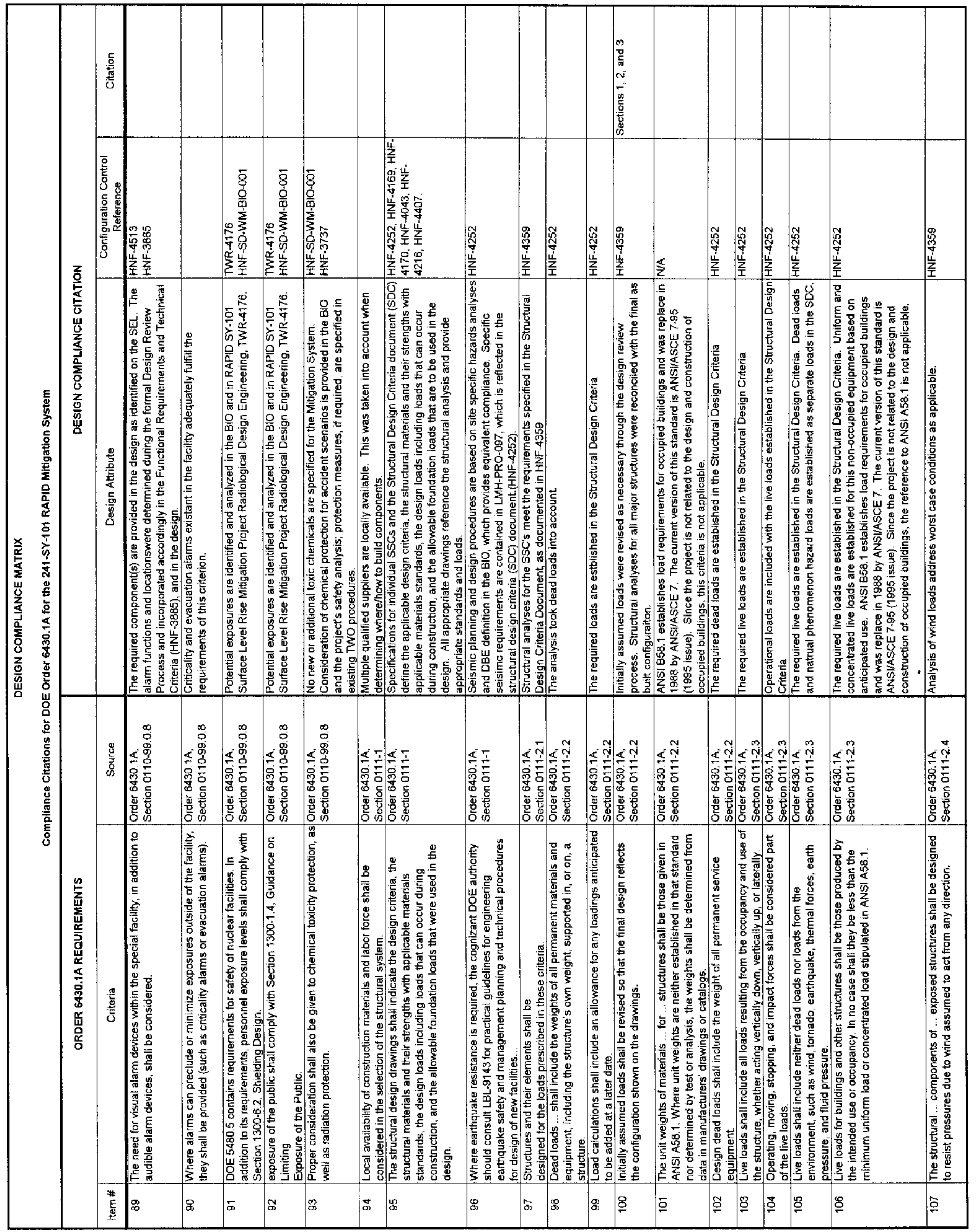




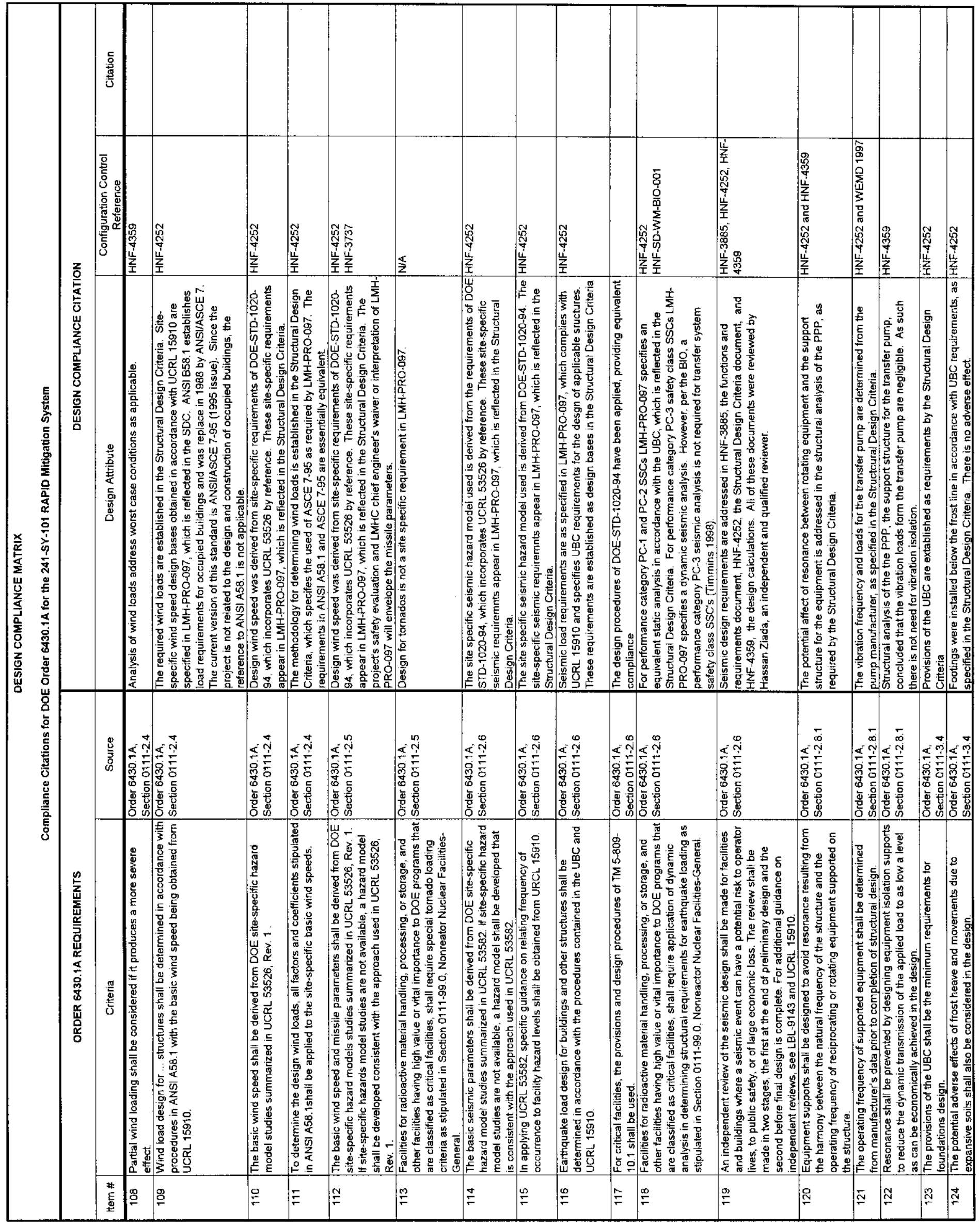




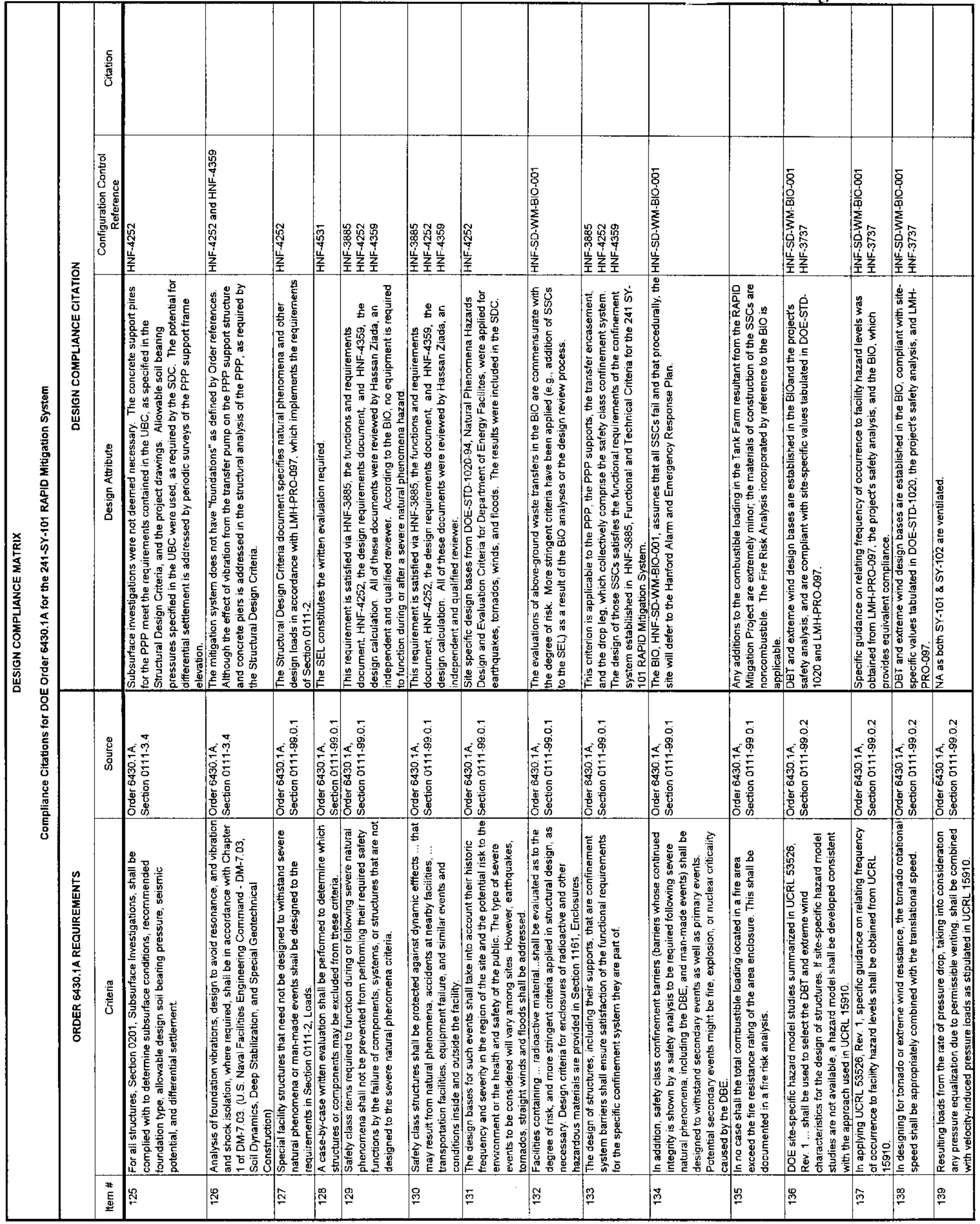




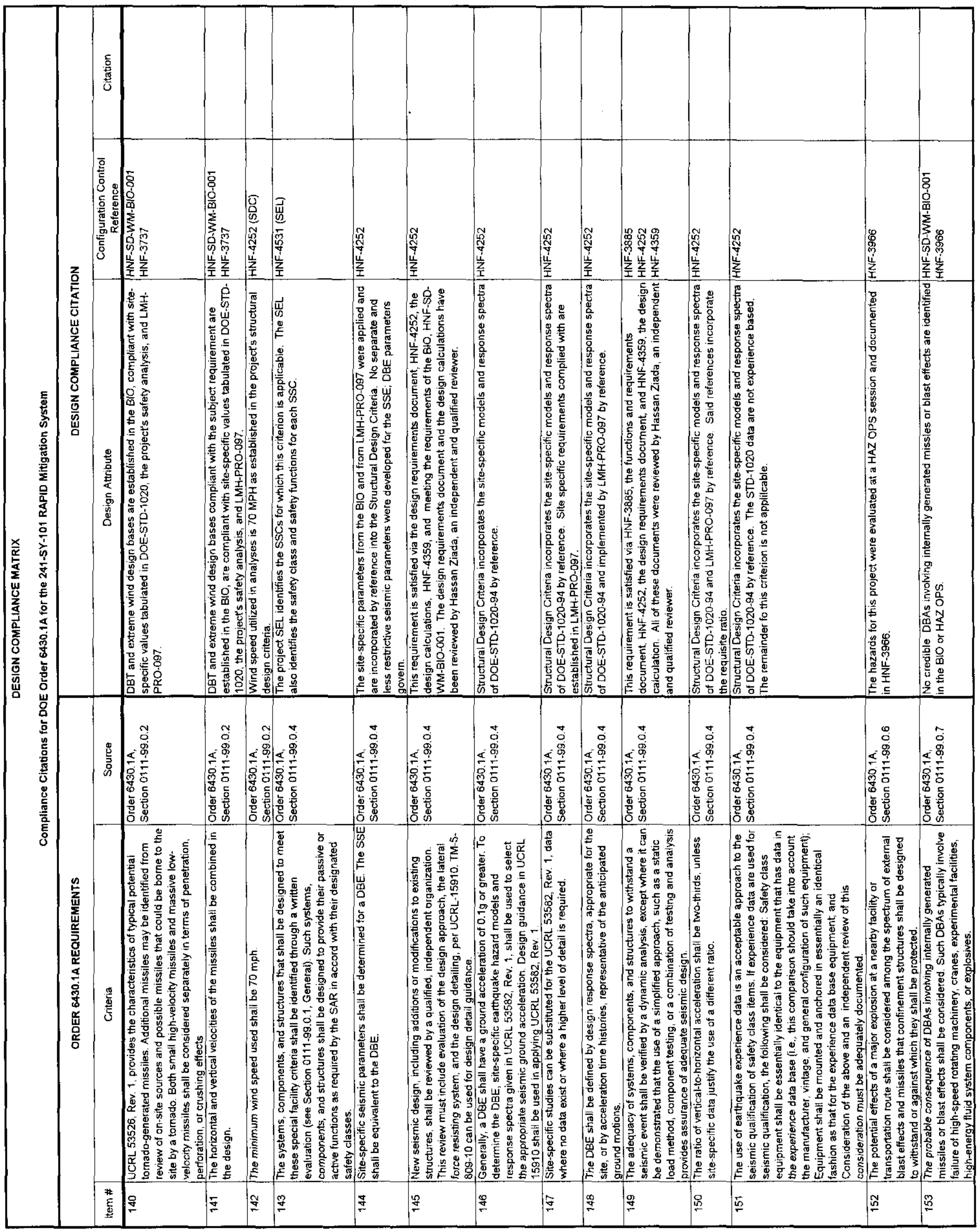


RPP-4993, Rev 1

Page 14 of 44

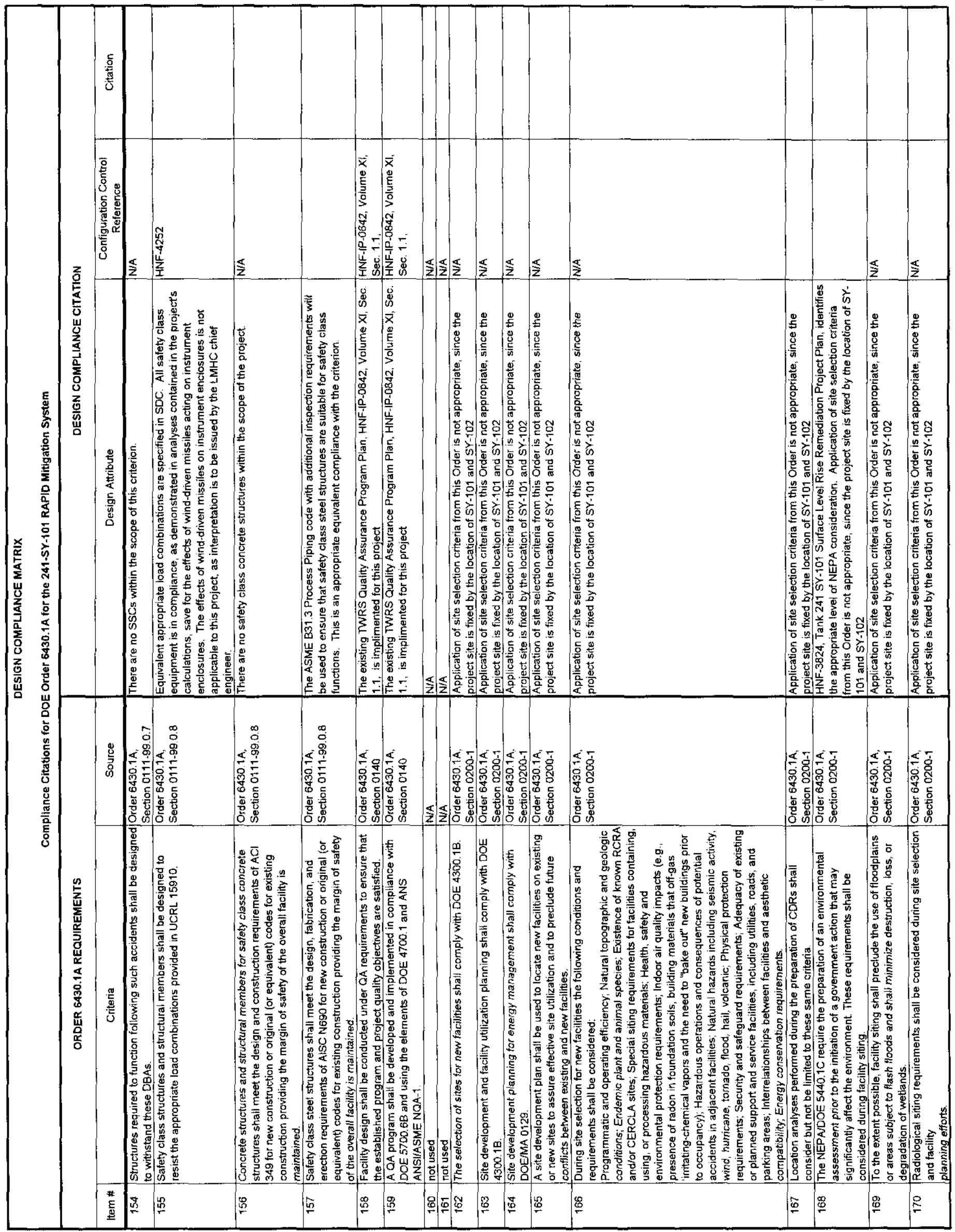




\section{RPP-4993, Rev 1 \\ Page 15 of 44}

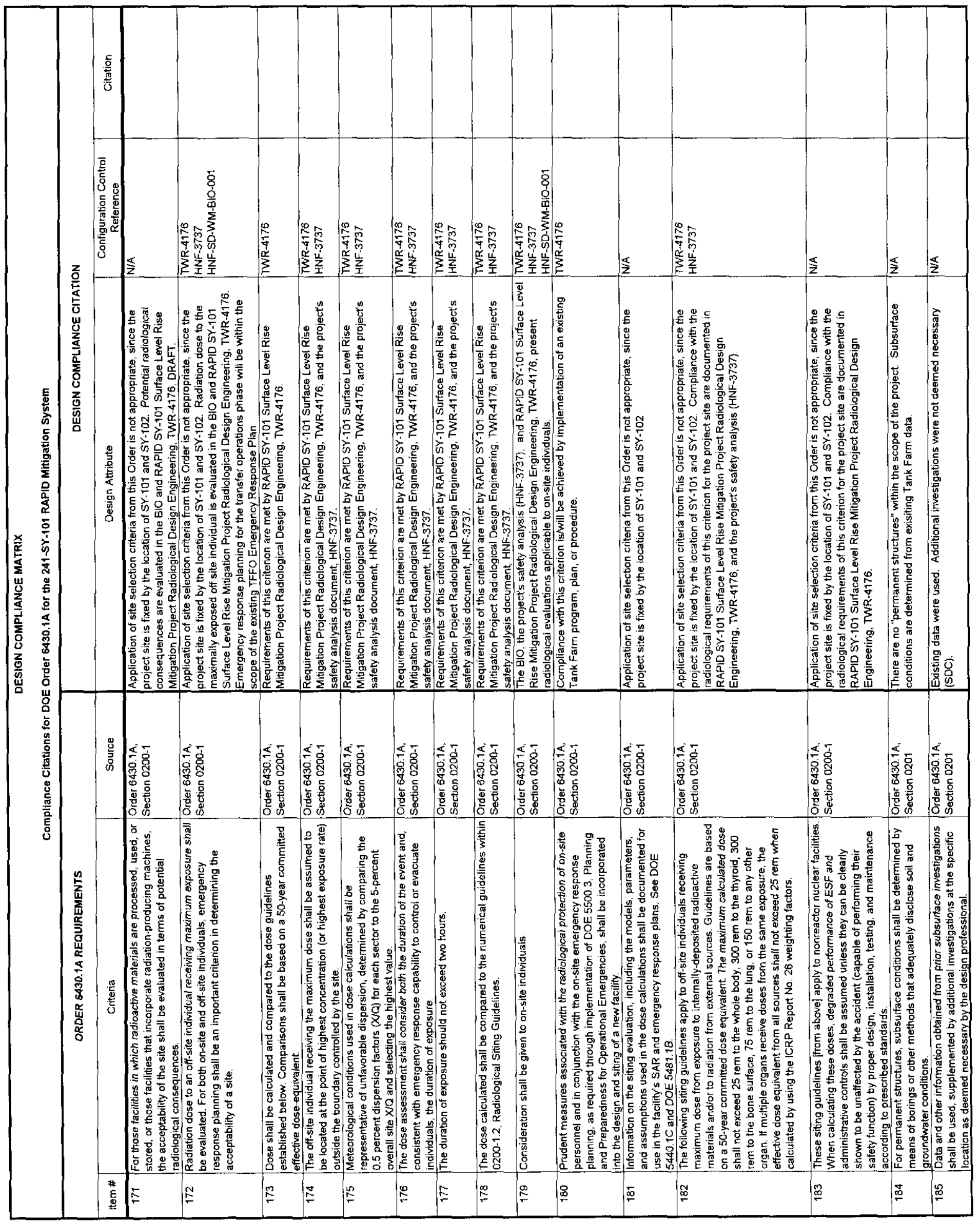


RPP-4993, Rev 1

Page 16 of 44

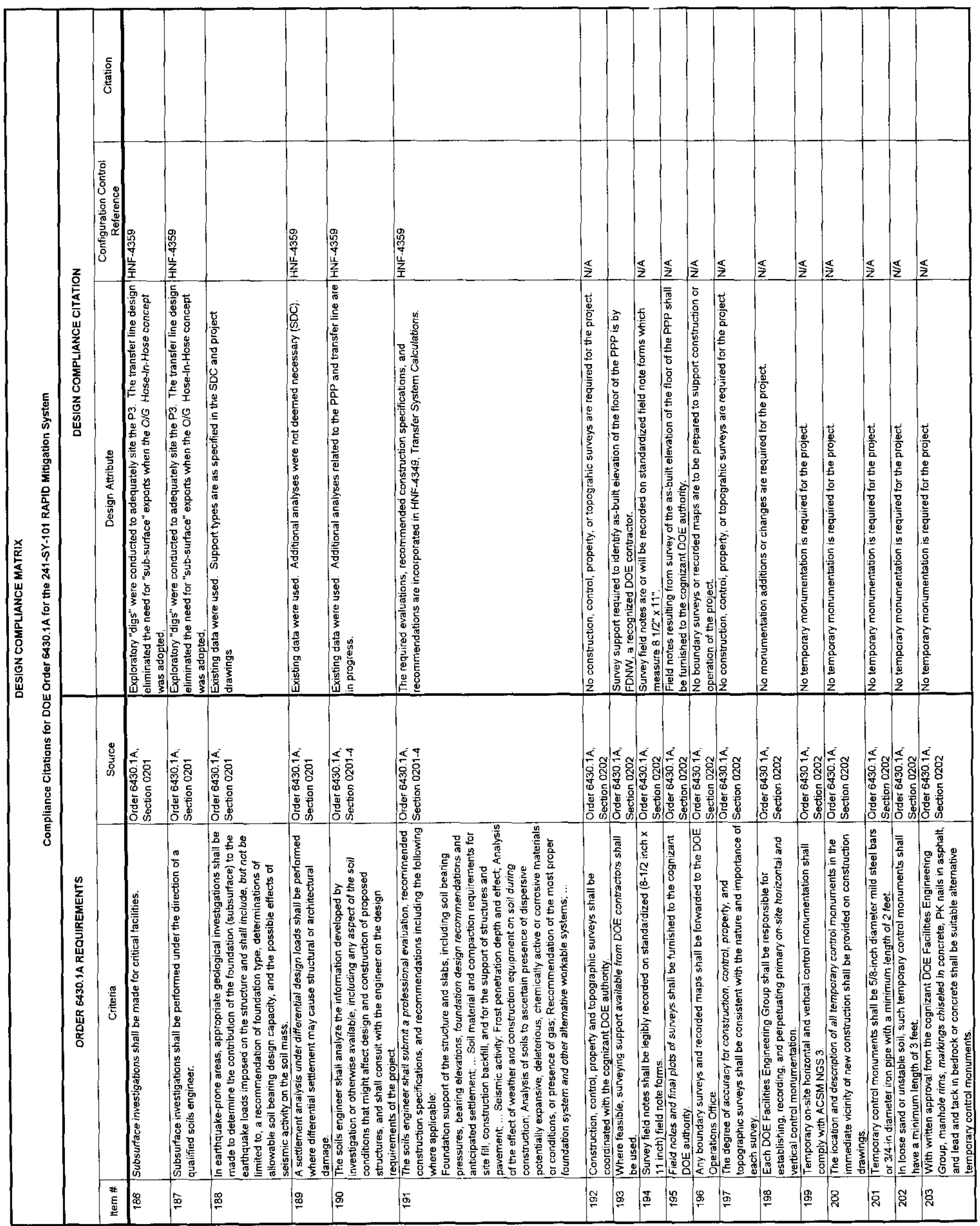




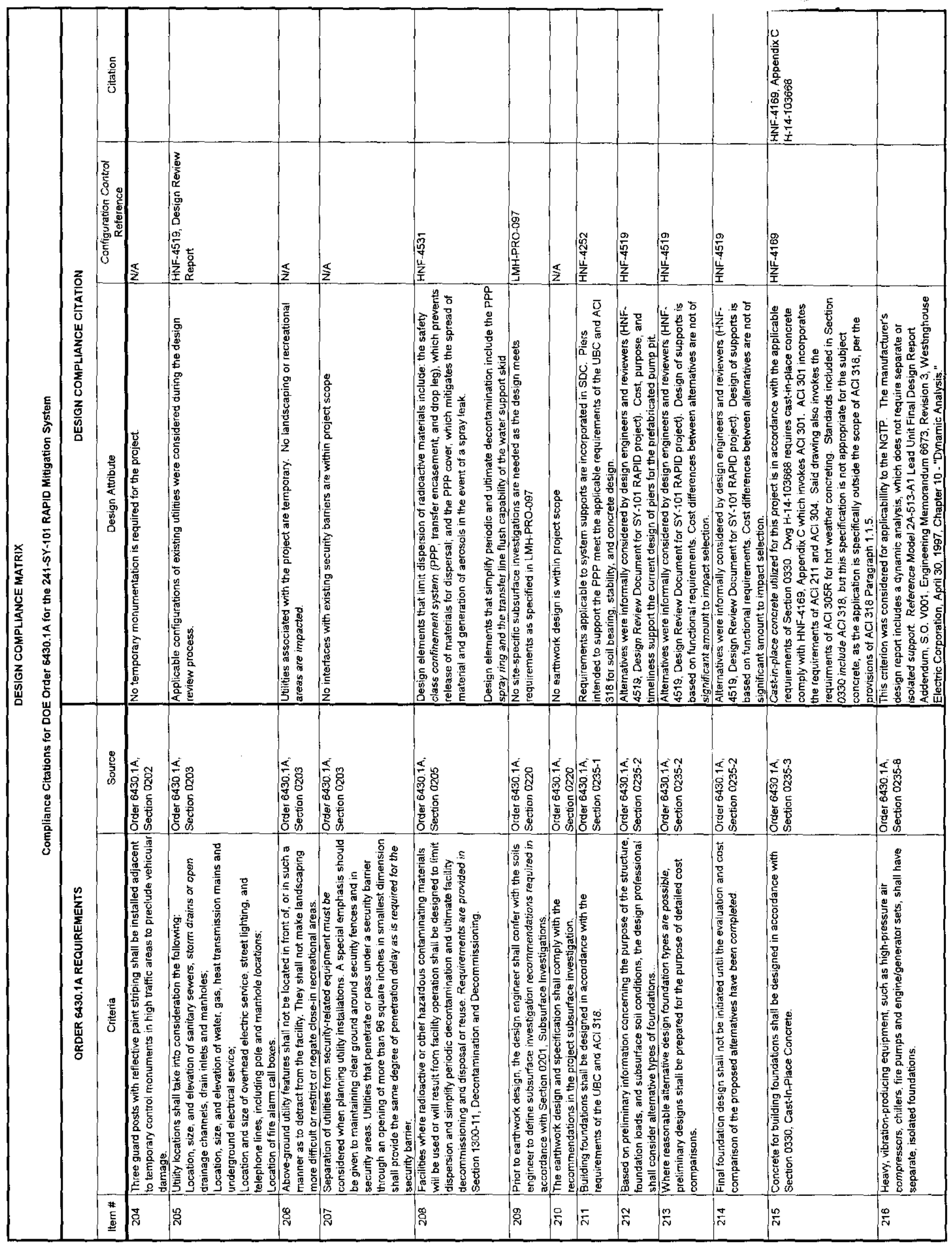


RPP-4993, Rev 1

Page 18 of 44

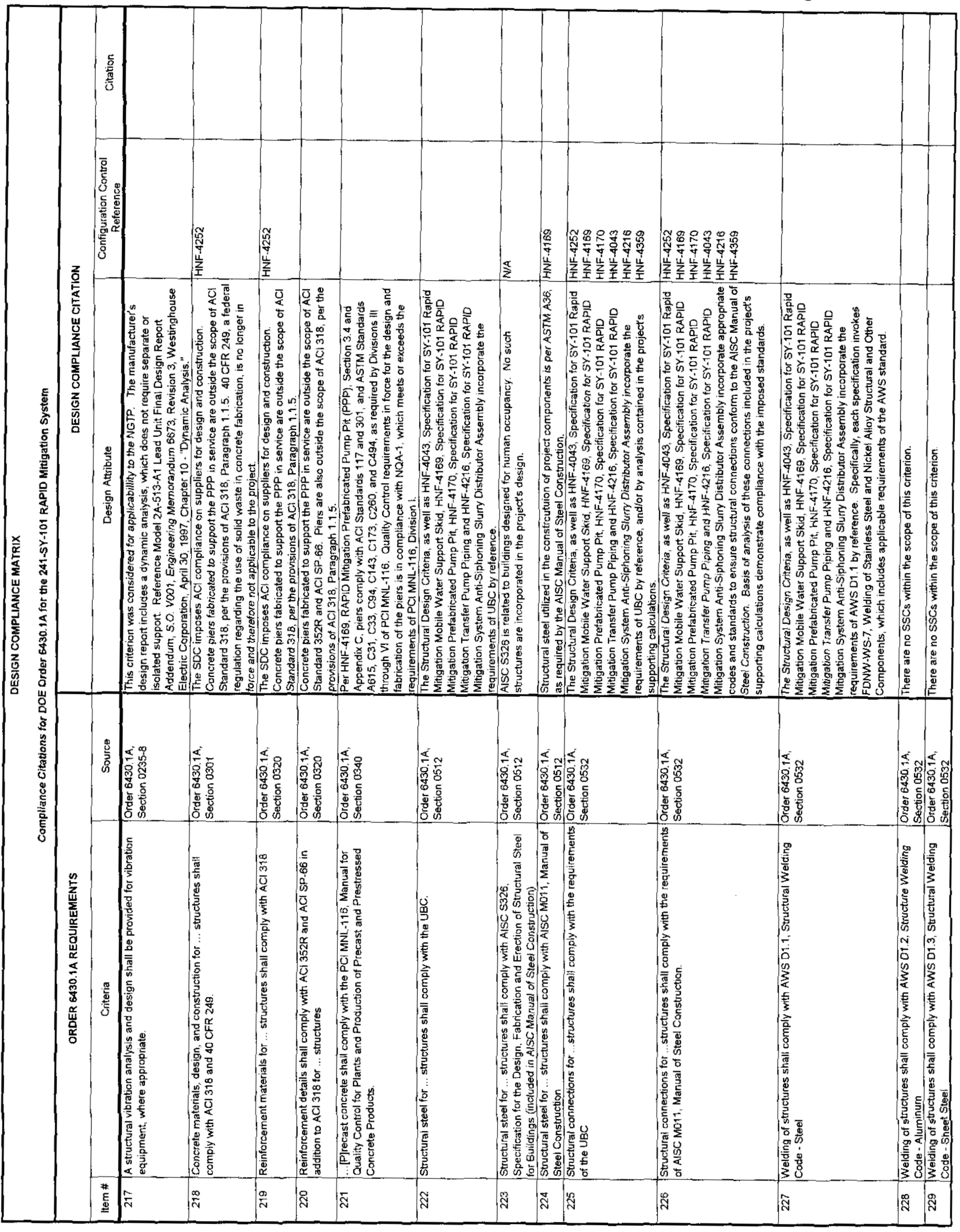


RPP-4993, Rev 1

Page 19 of 44

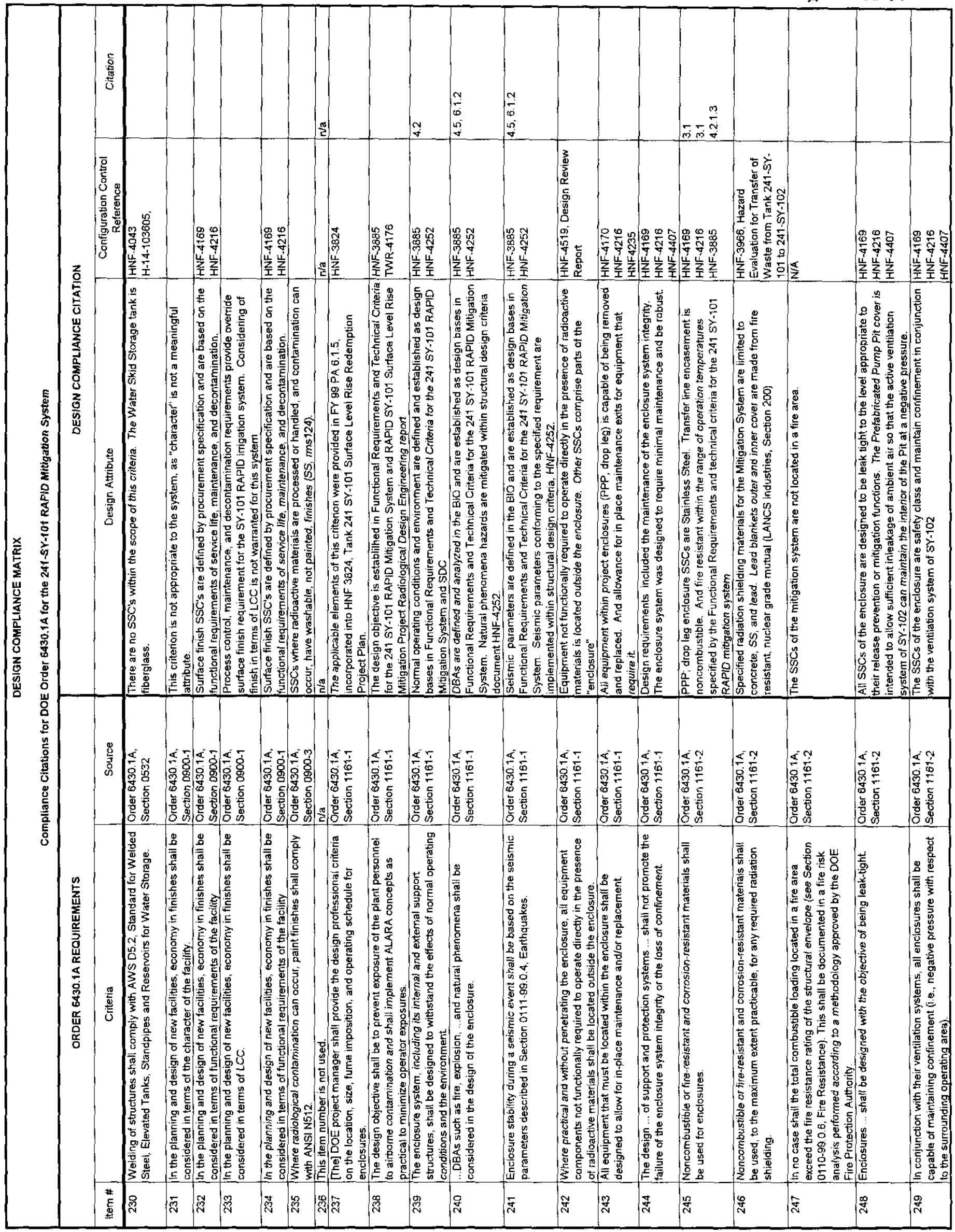


RPP-4993, Rev 1

Page 20 of 44

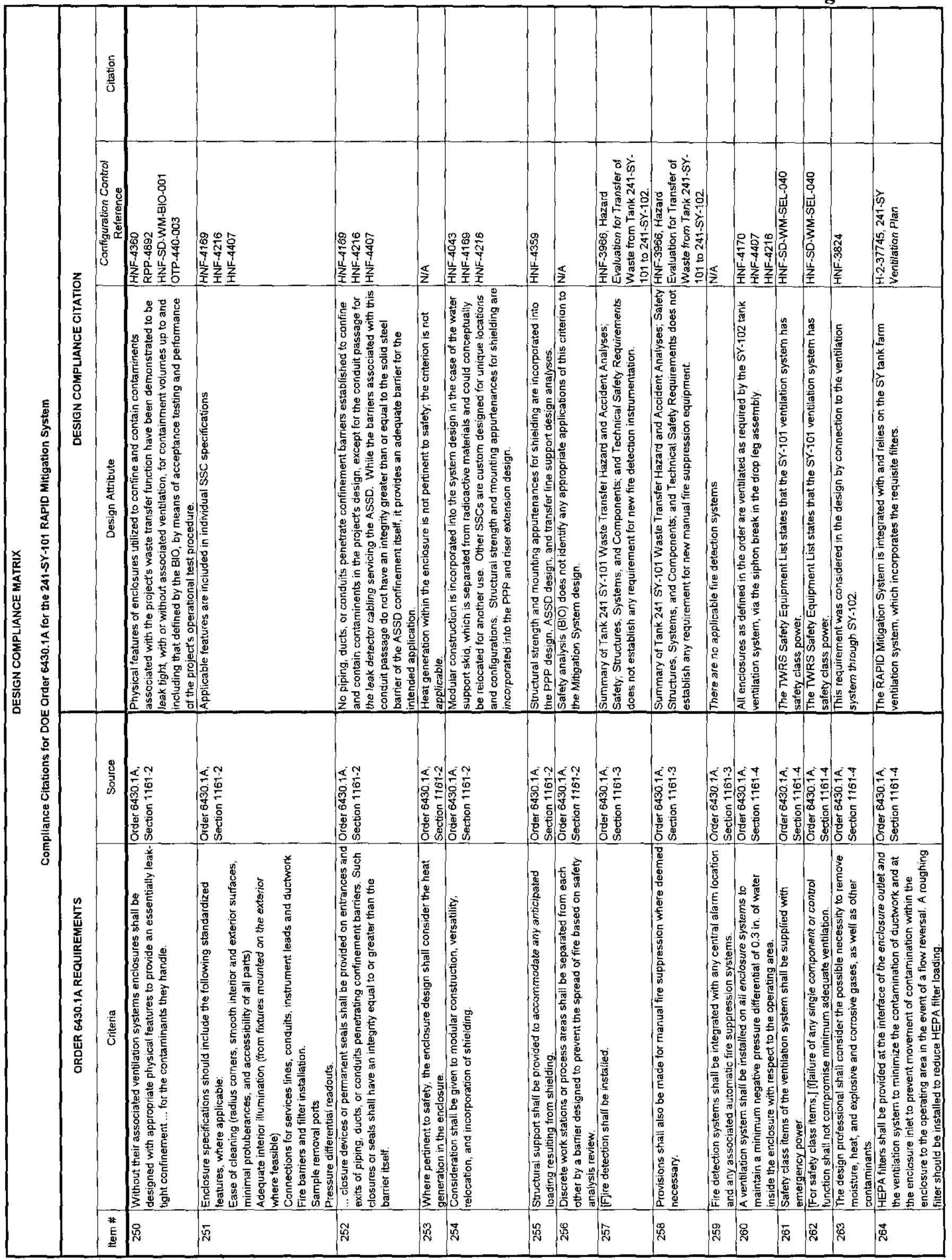


RPP-4993, Rev 1

Page 21 of 44

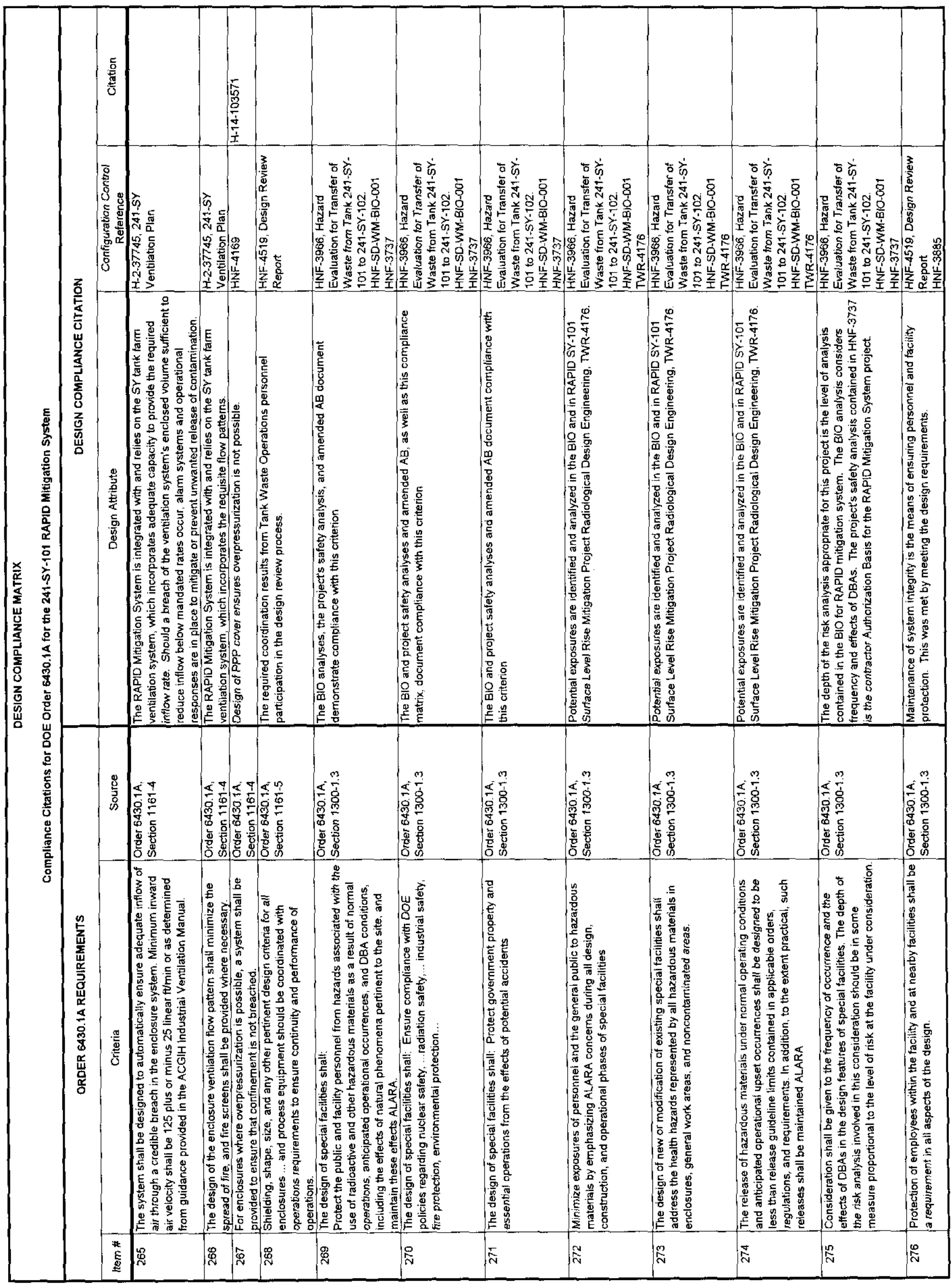




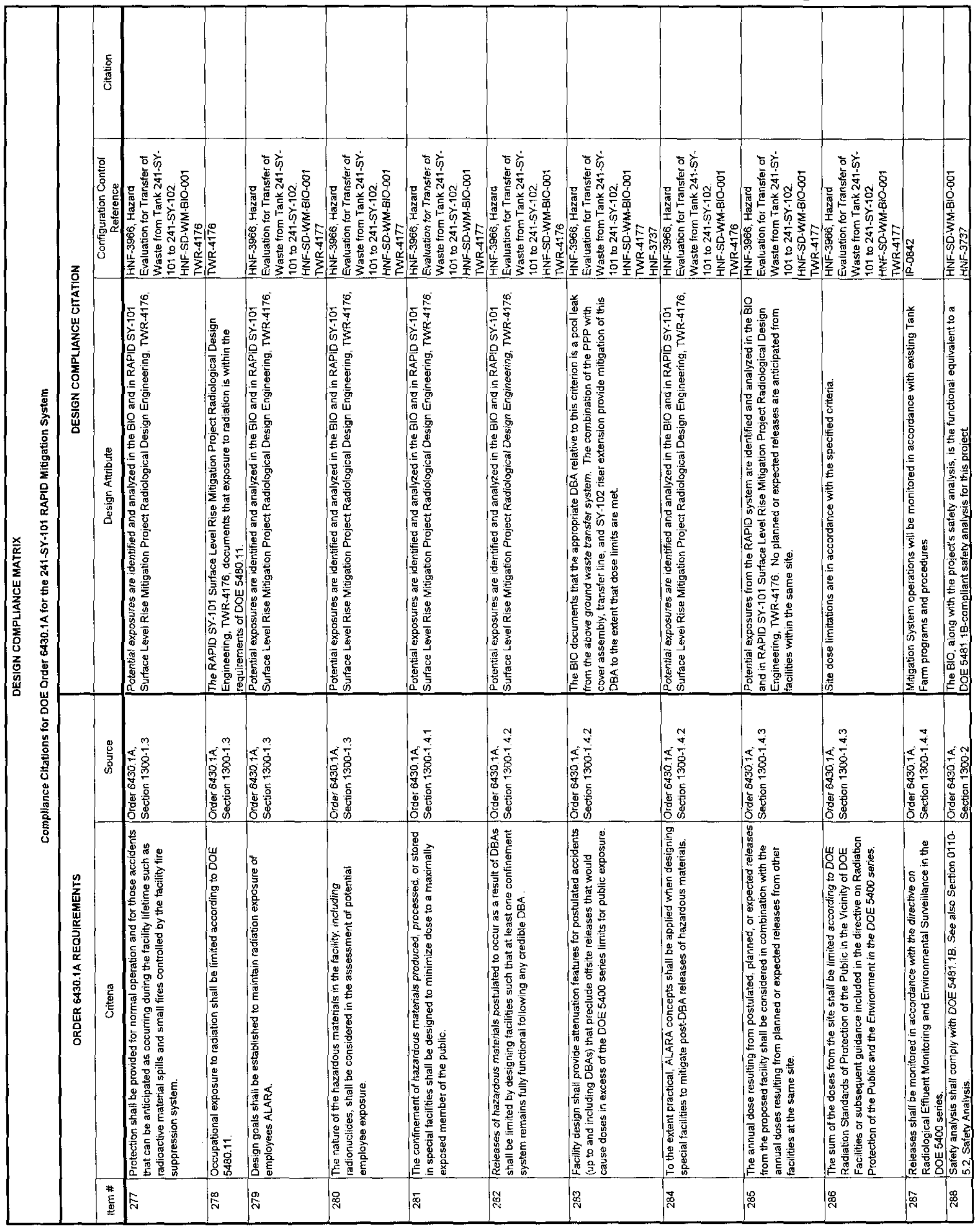




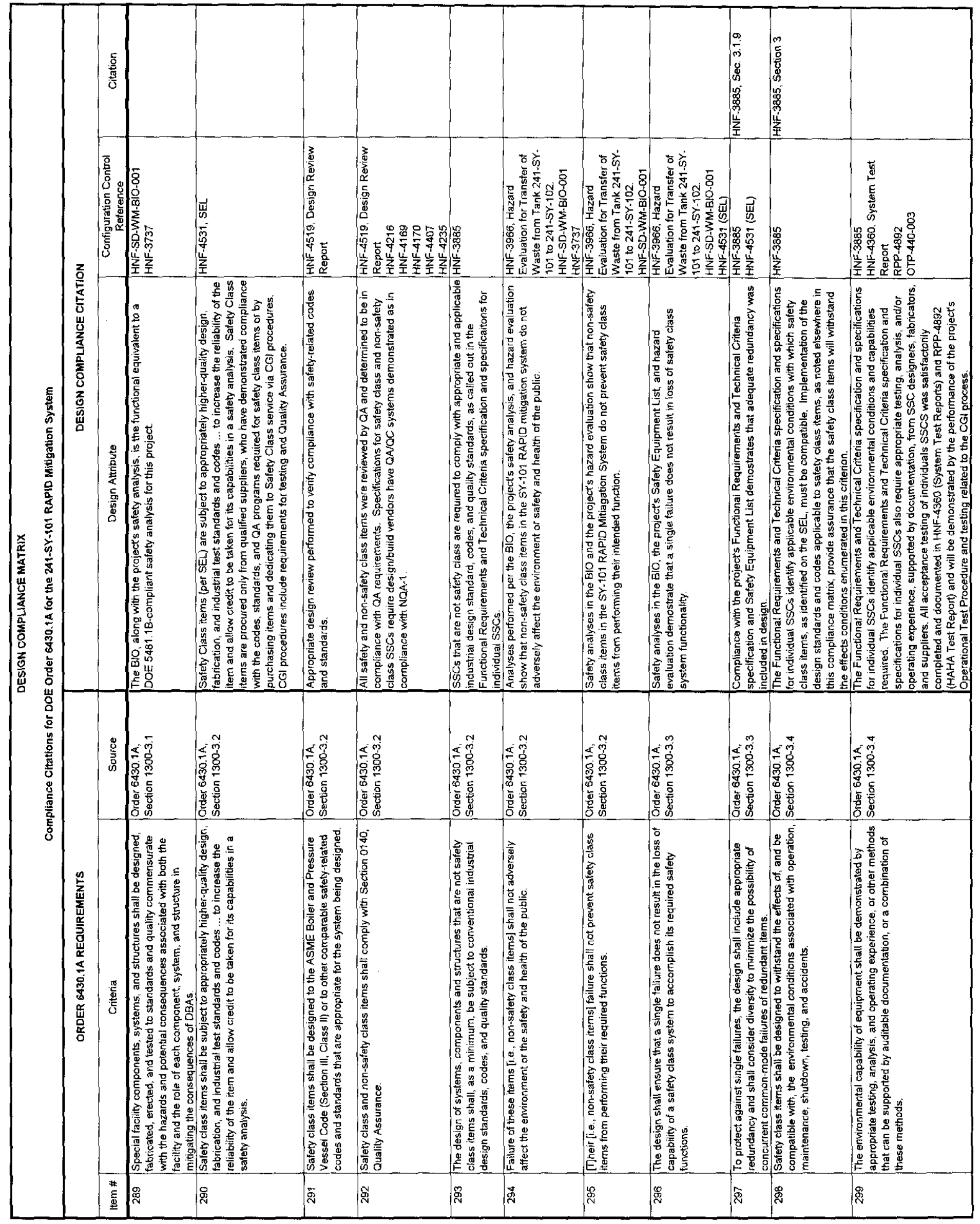




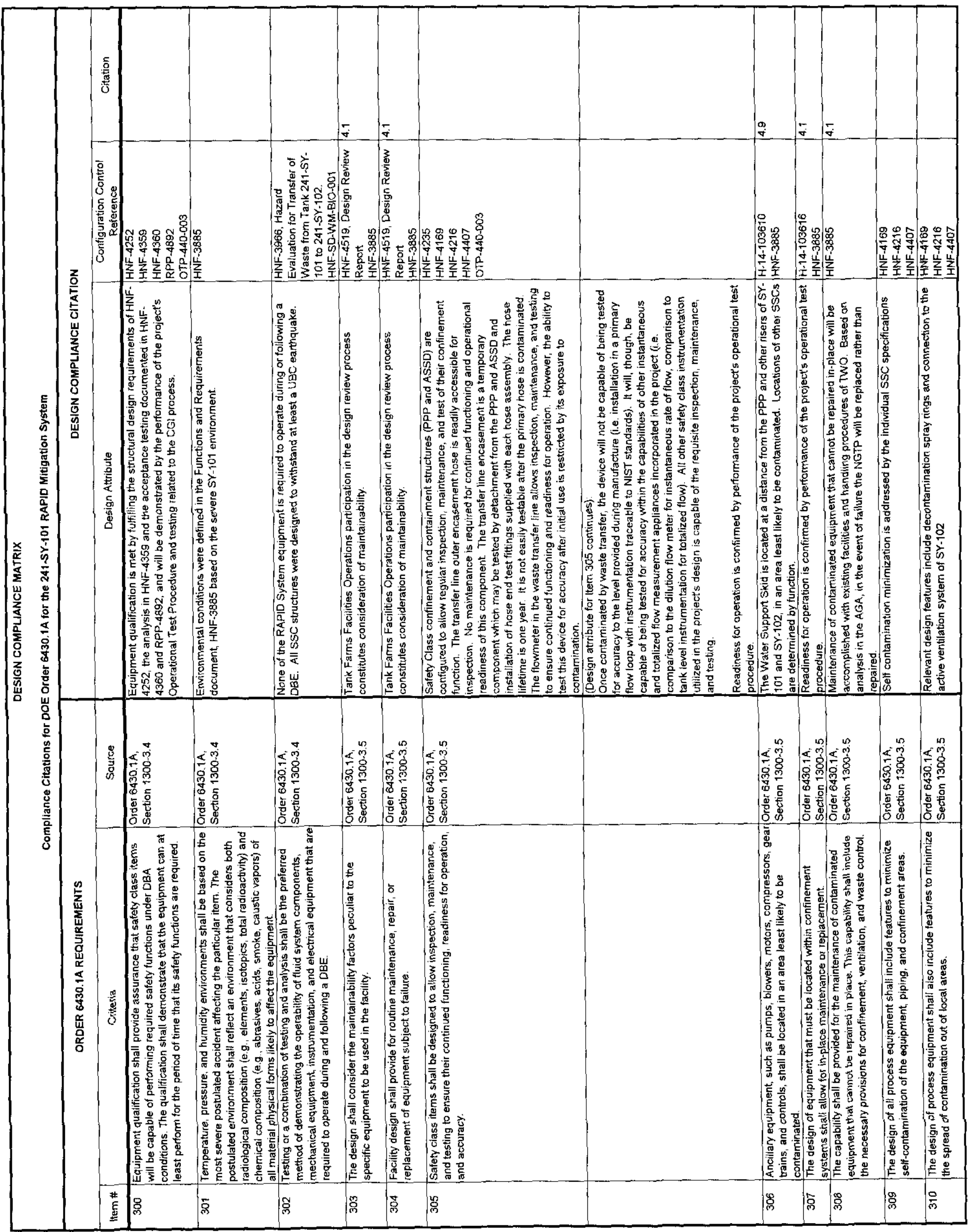


RPP-4993, Rev 1

Page 25 of 44

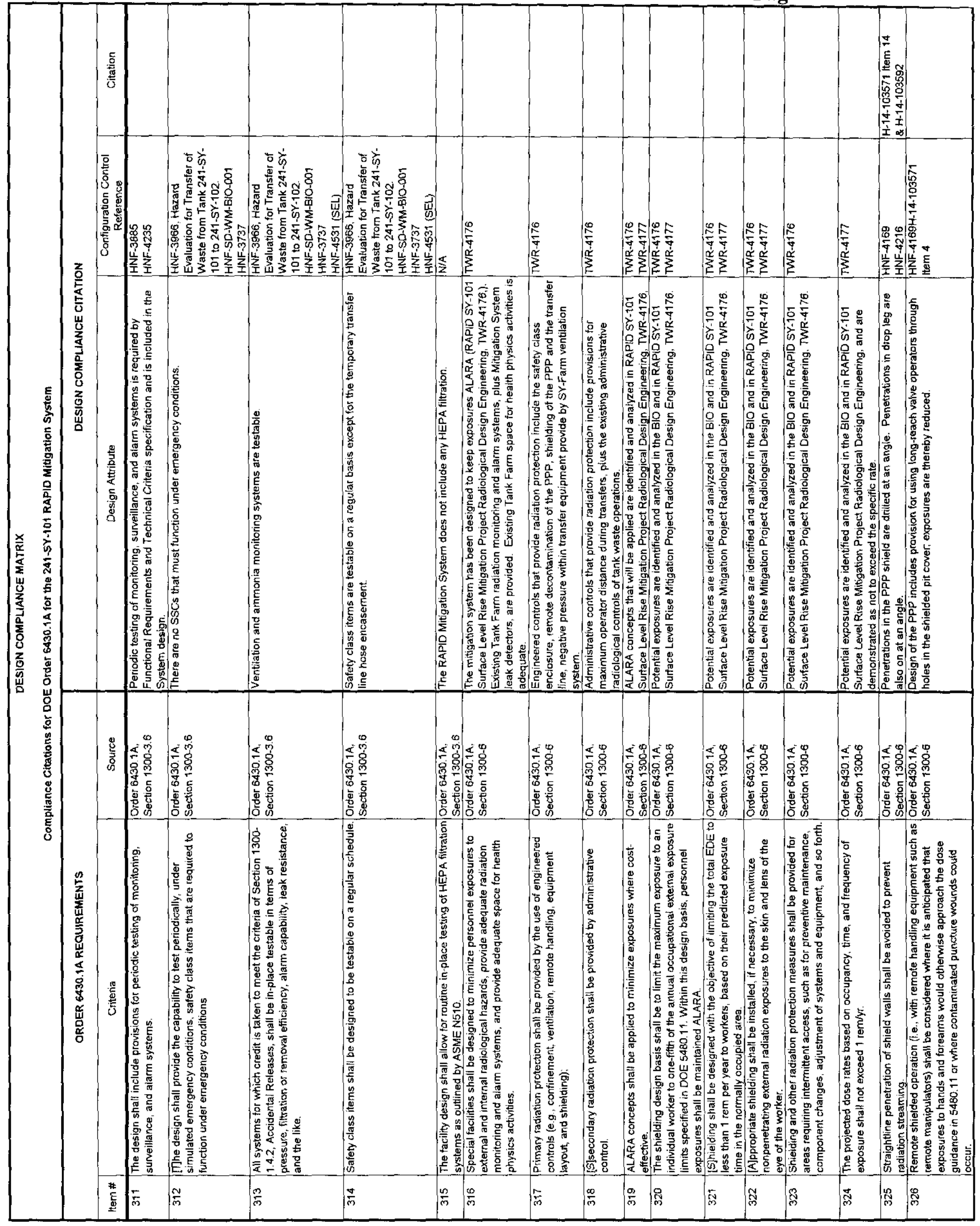




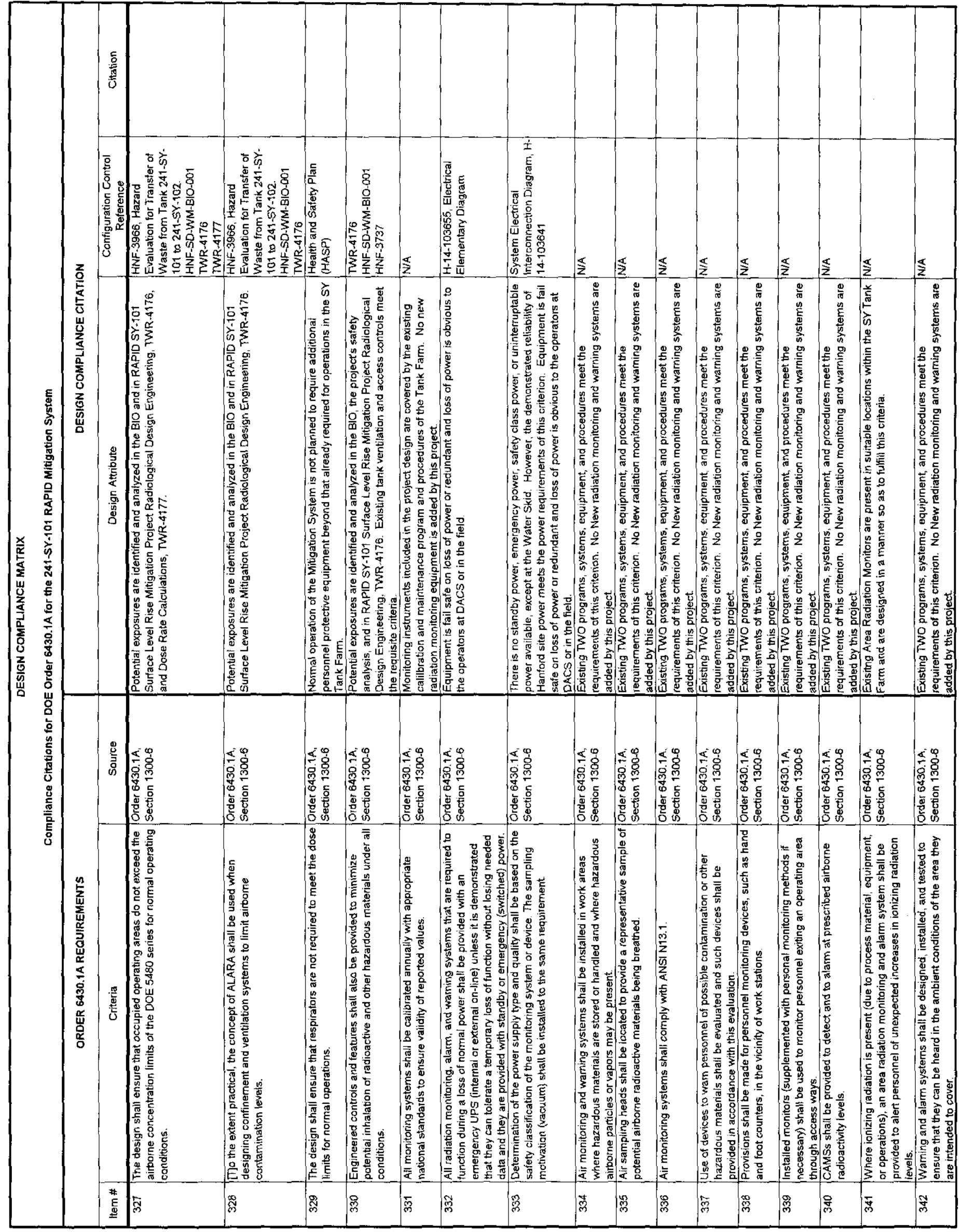




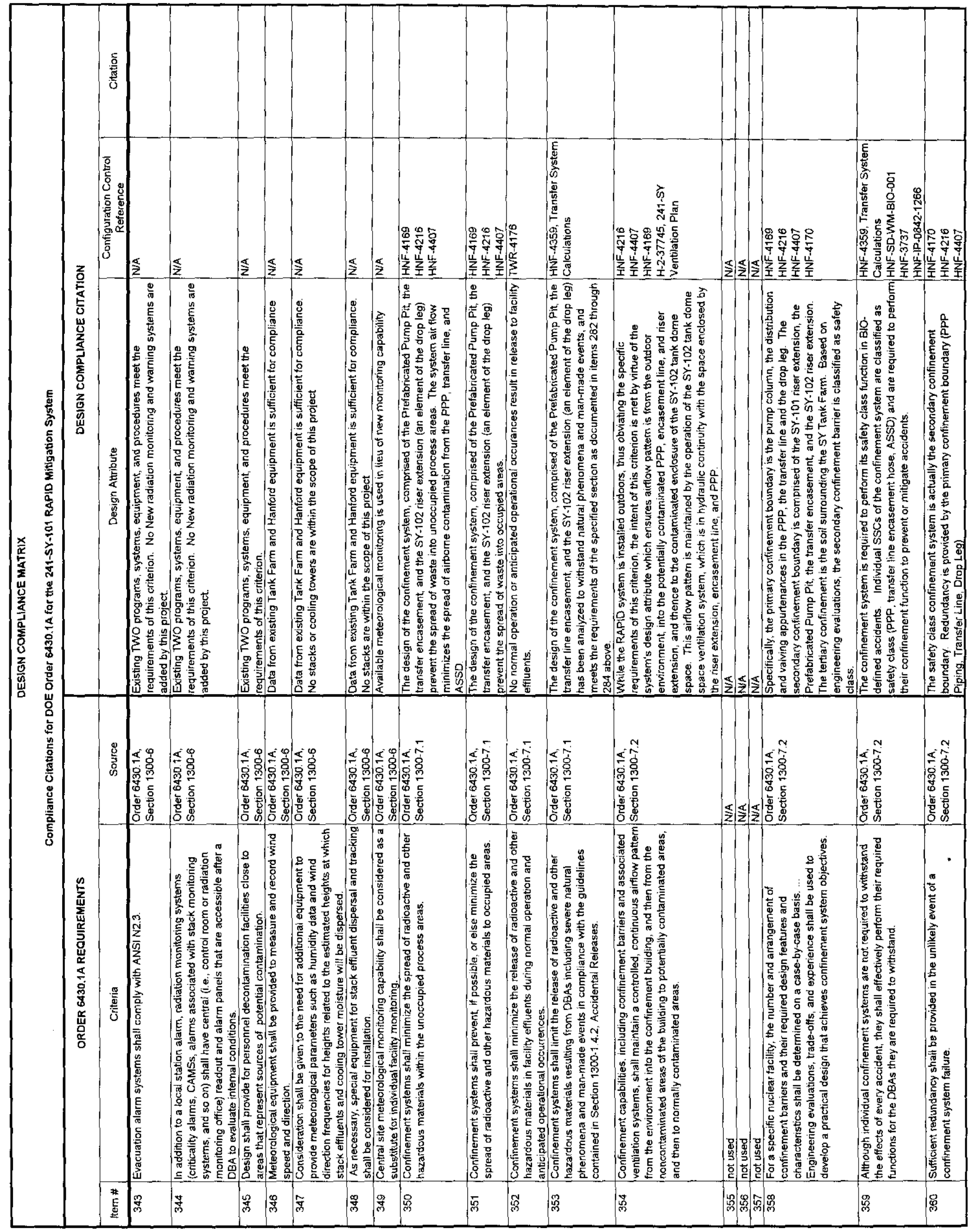


RPP-4993, Rev 1

Page 28 of 44

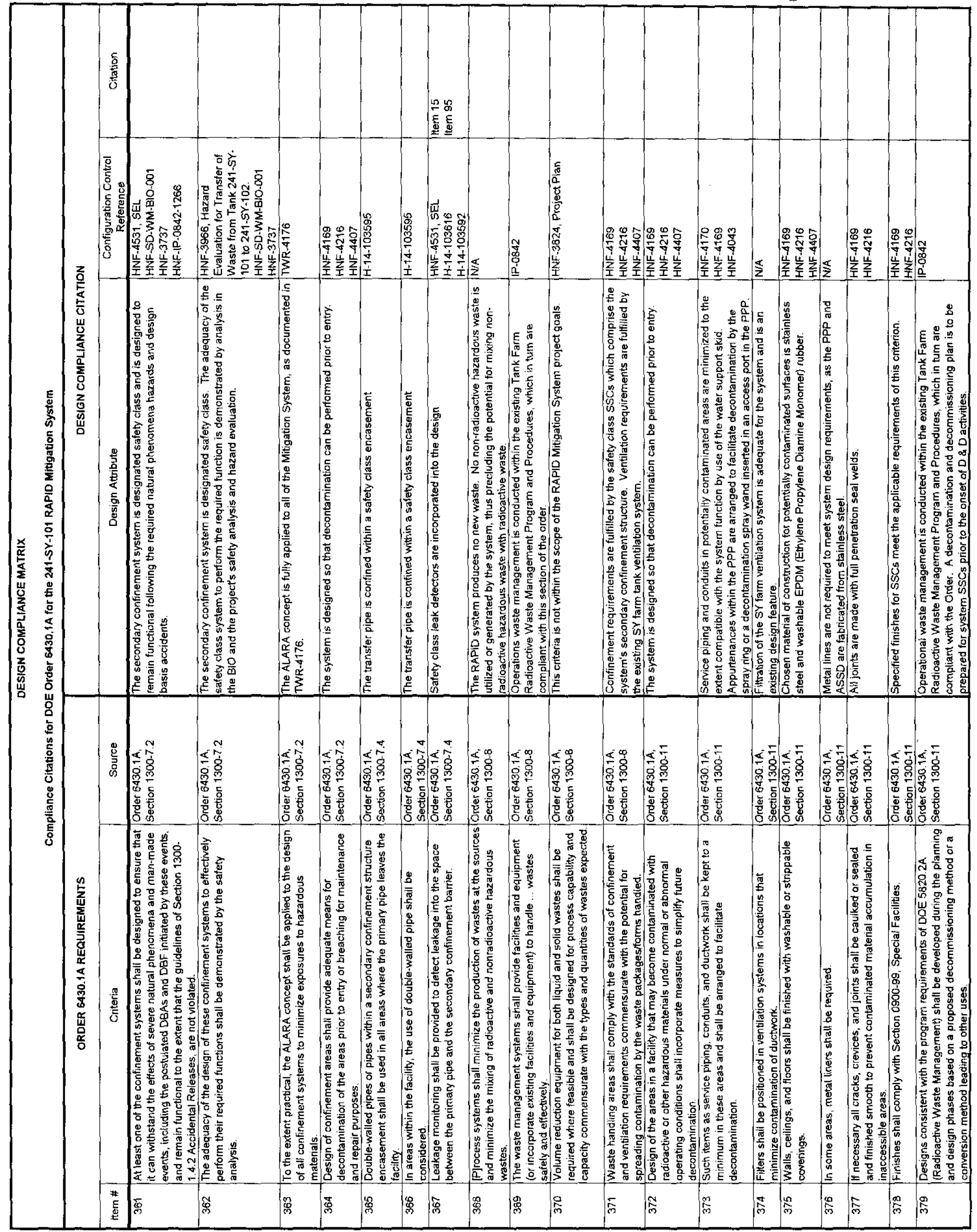


RPP-4993, Rev 1

Page 29 of 44

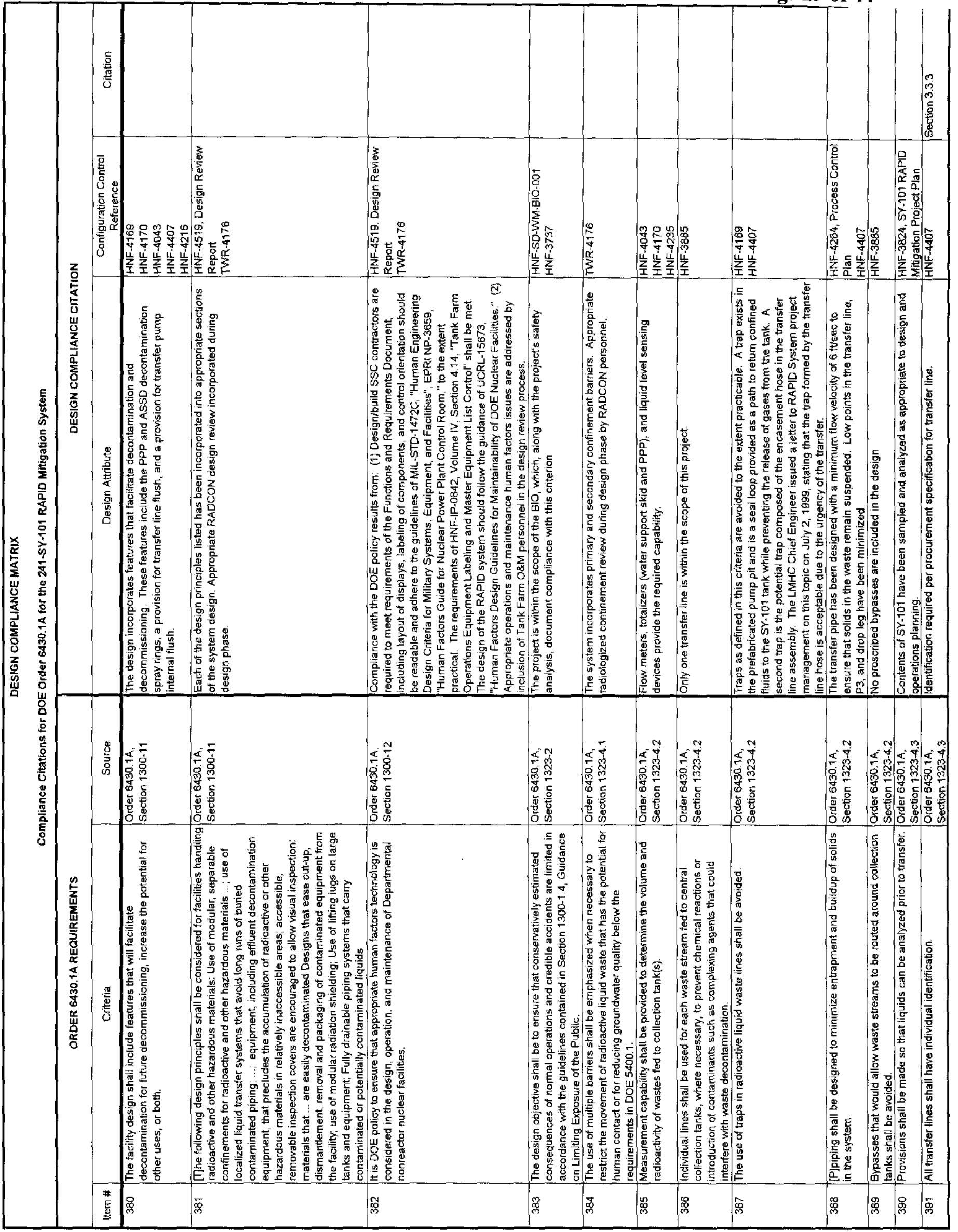




\section{RPP-4993, Rev 1 \\ Page 30 of 44}

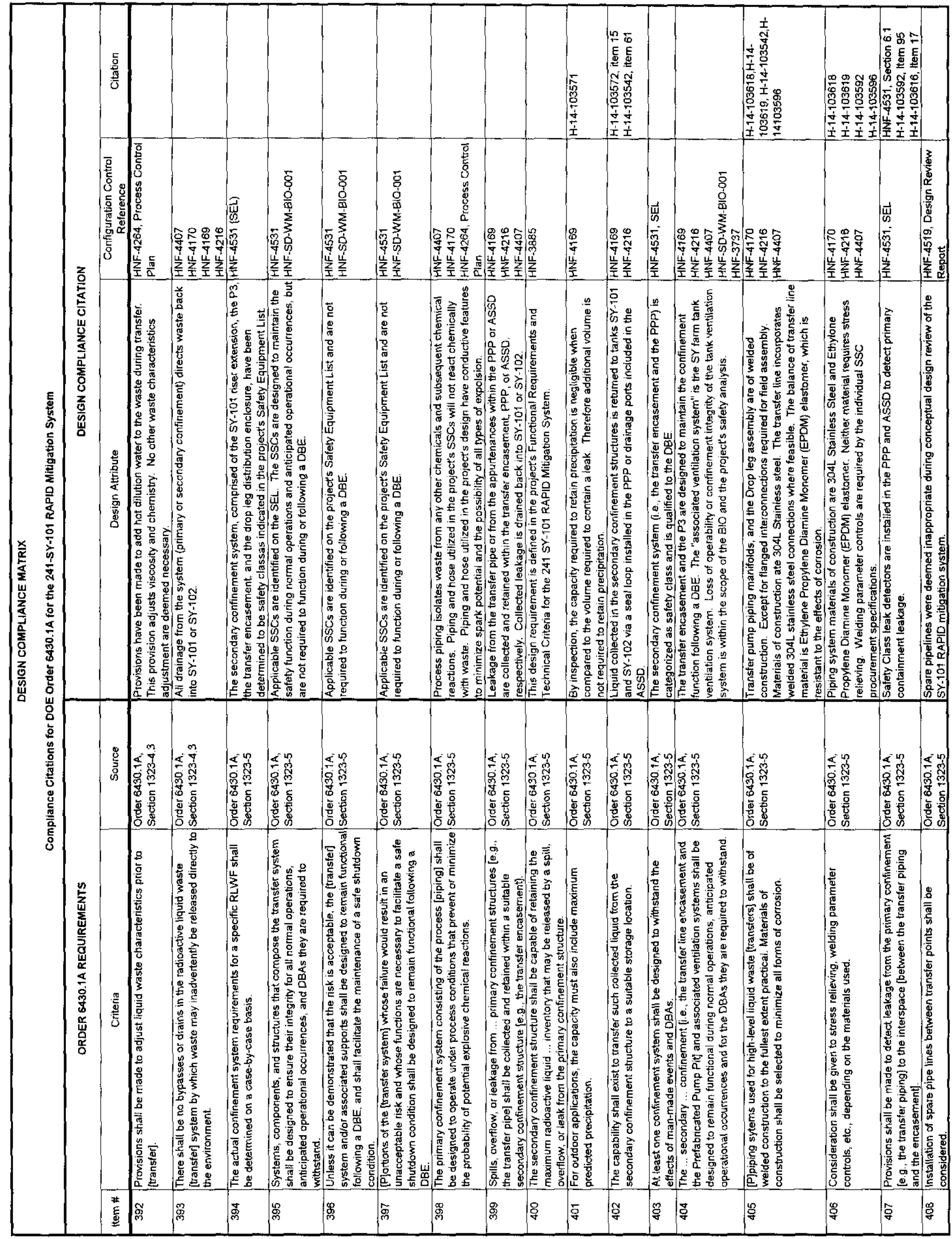




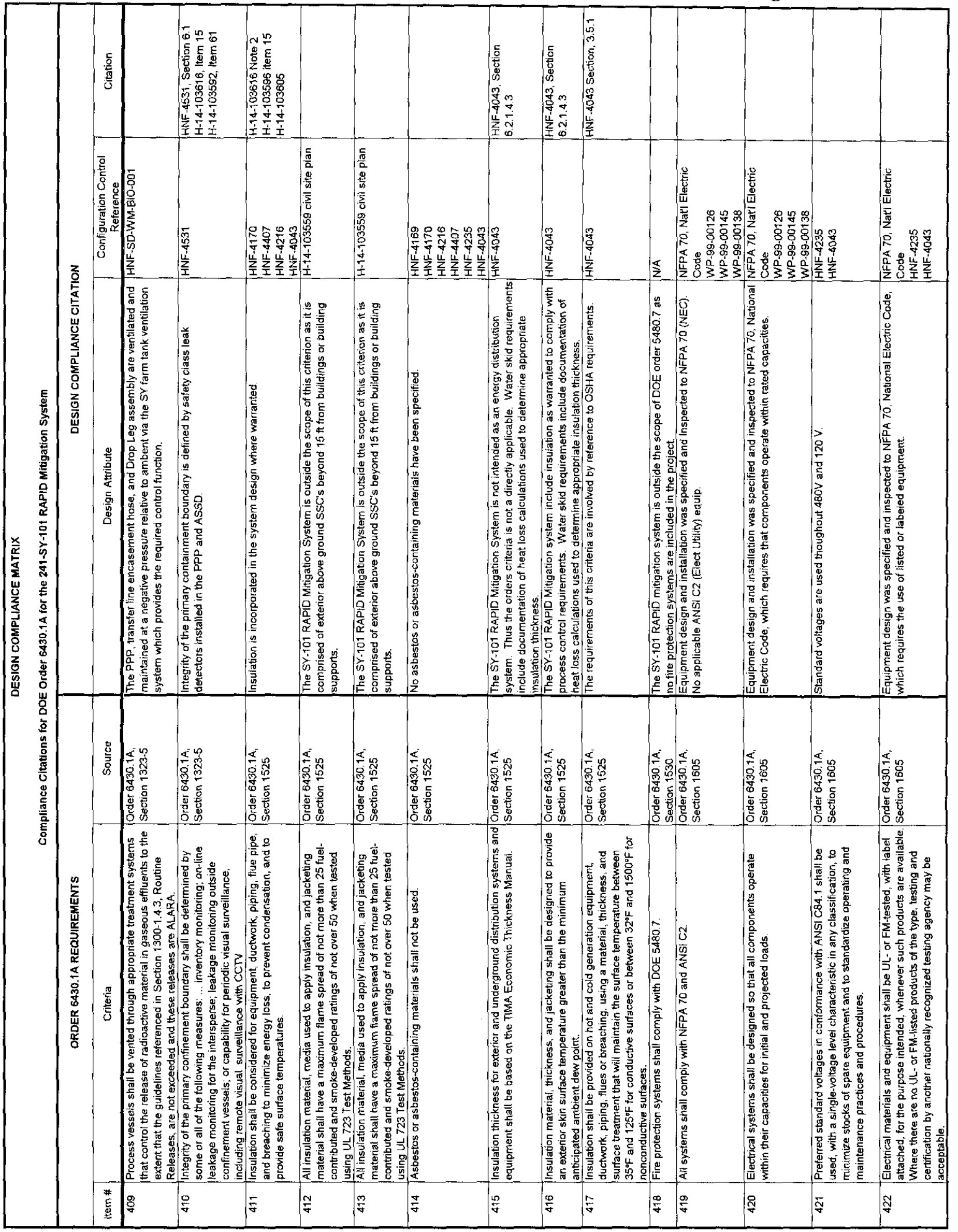




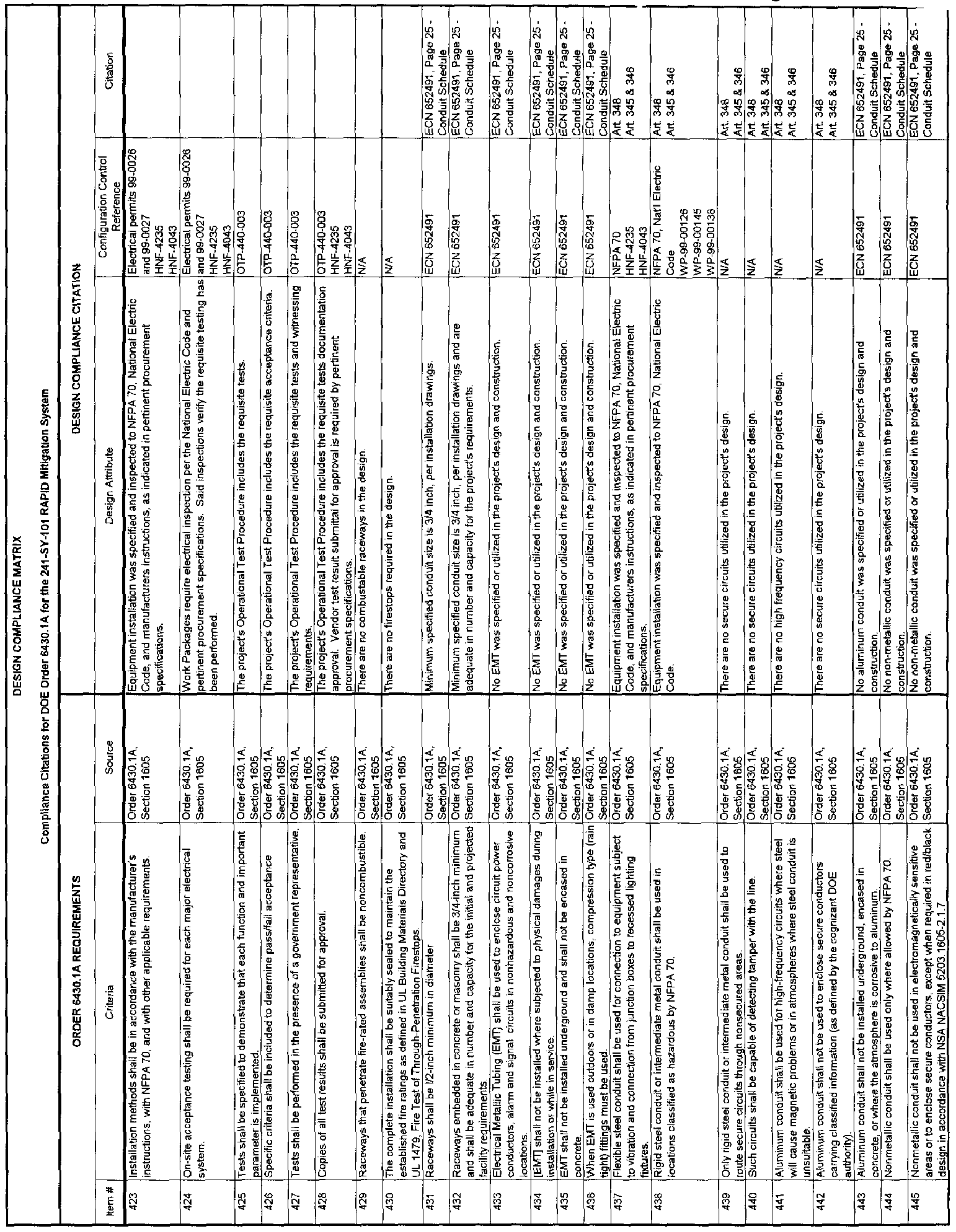




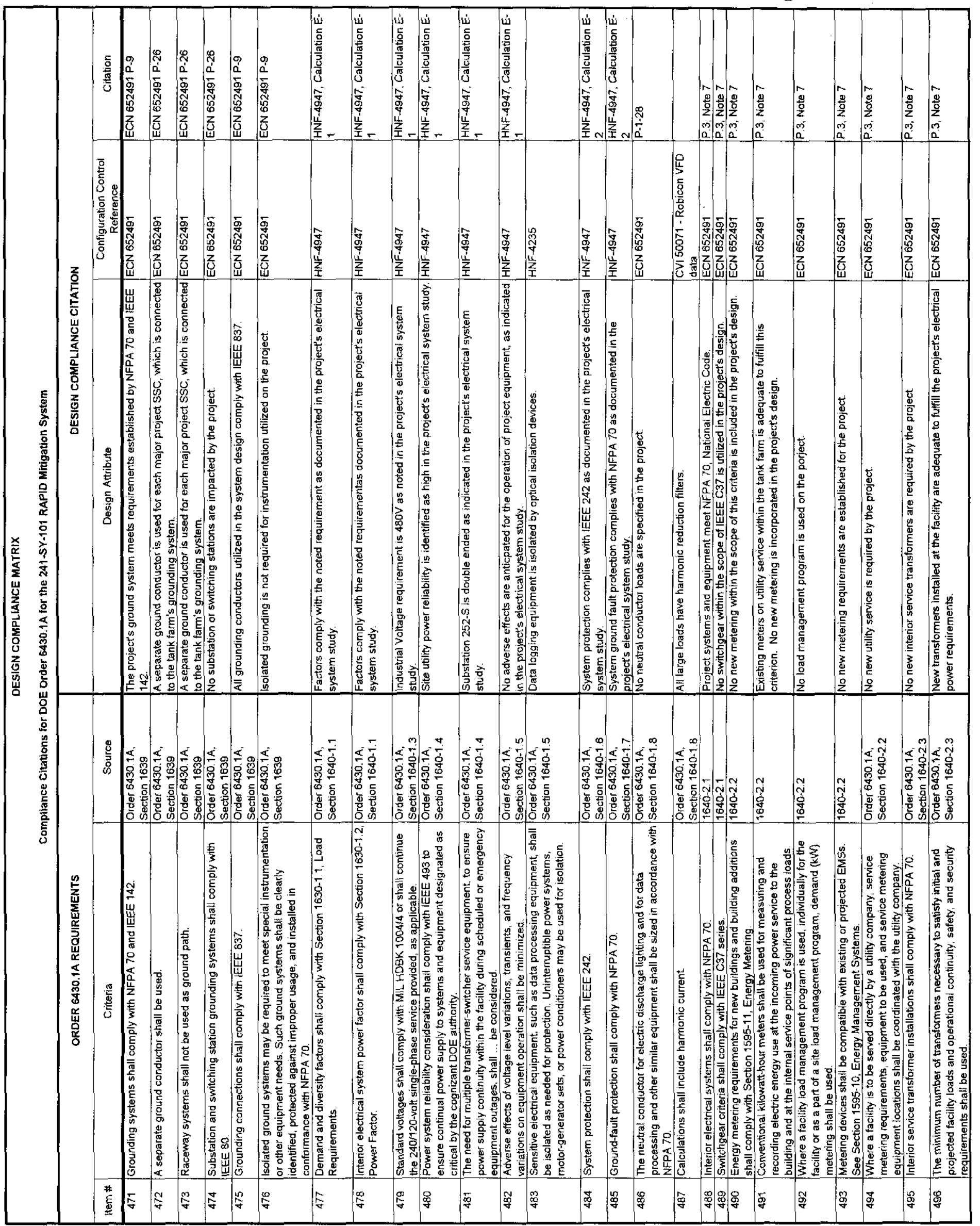




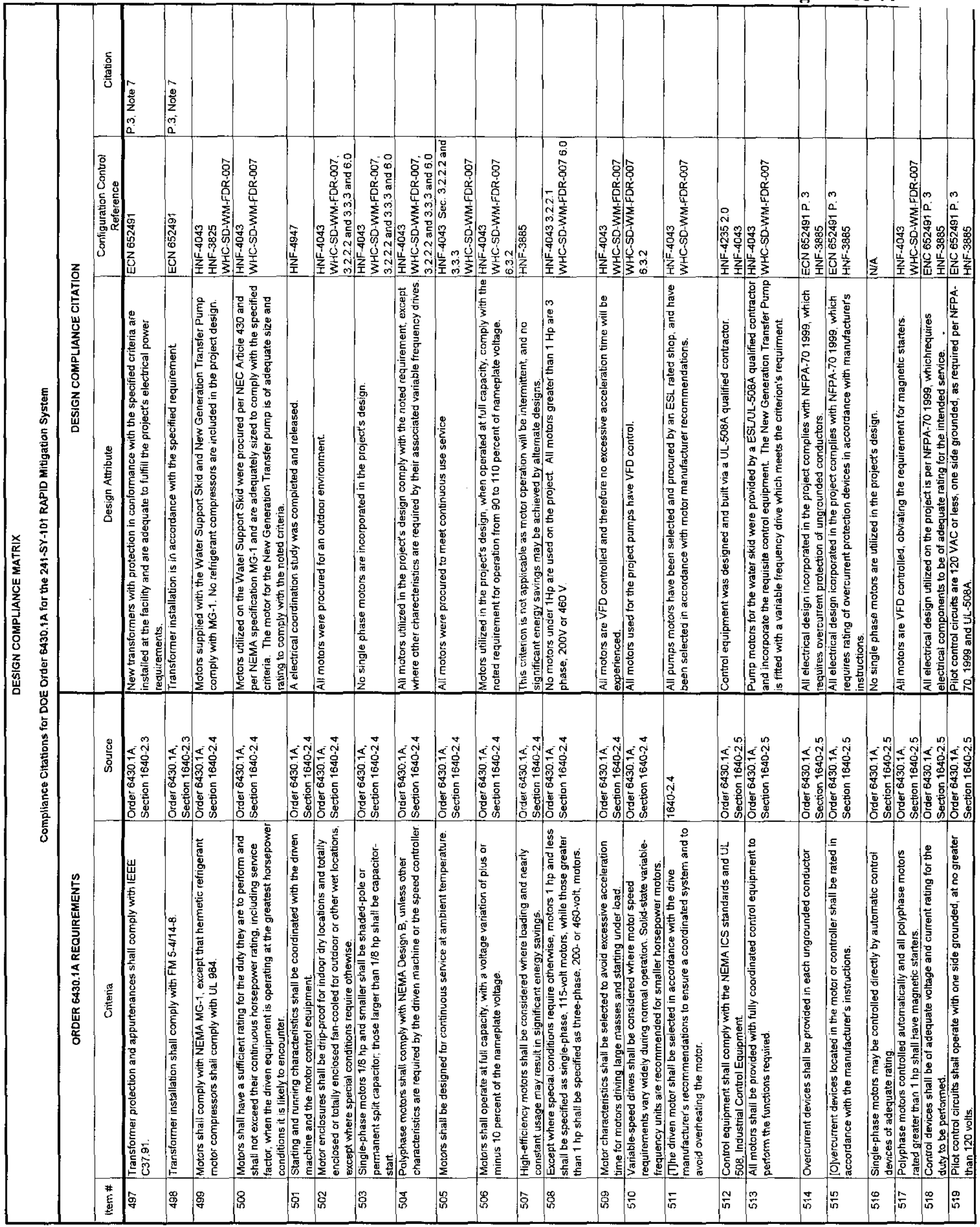




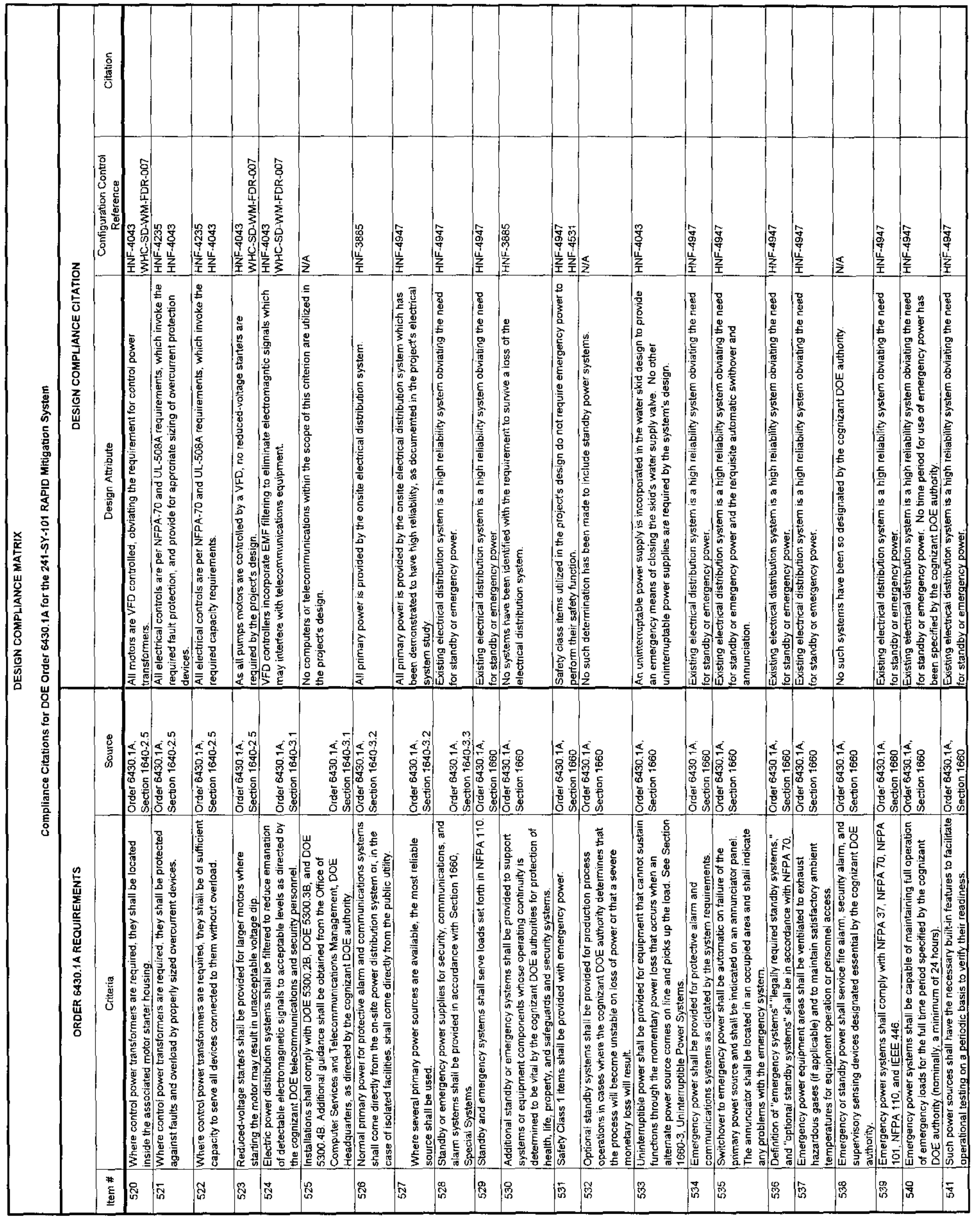




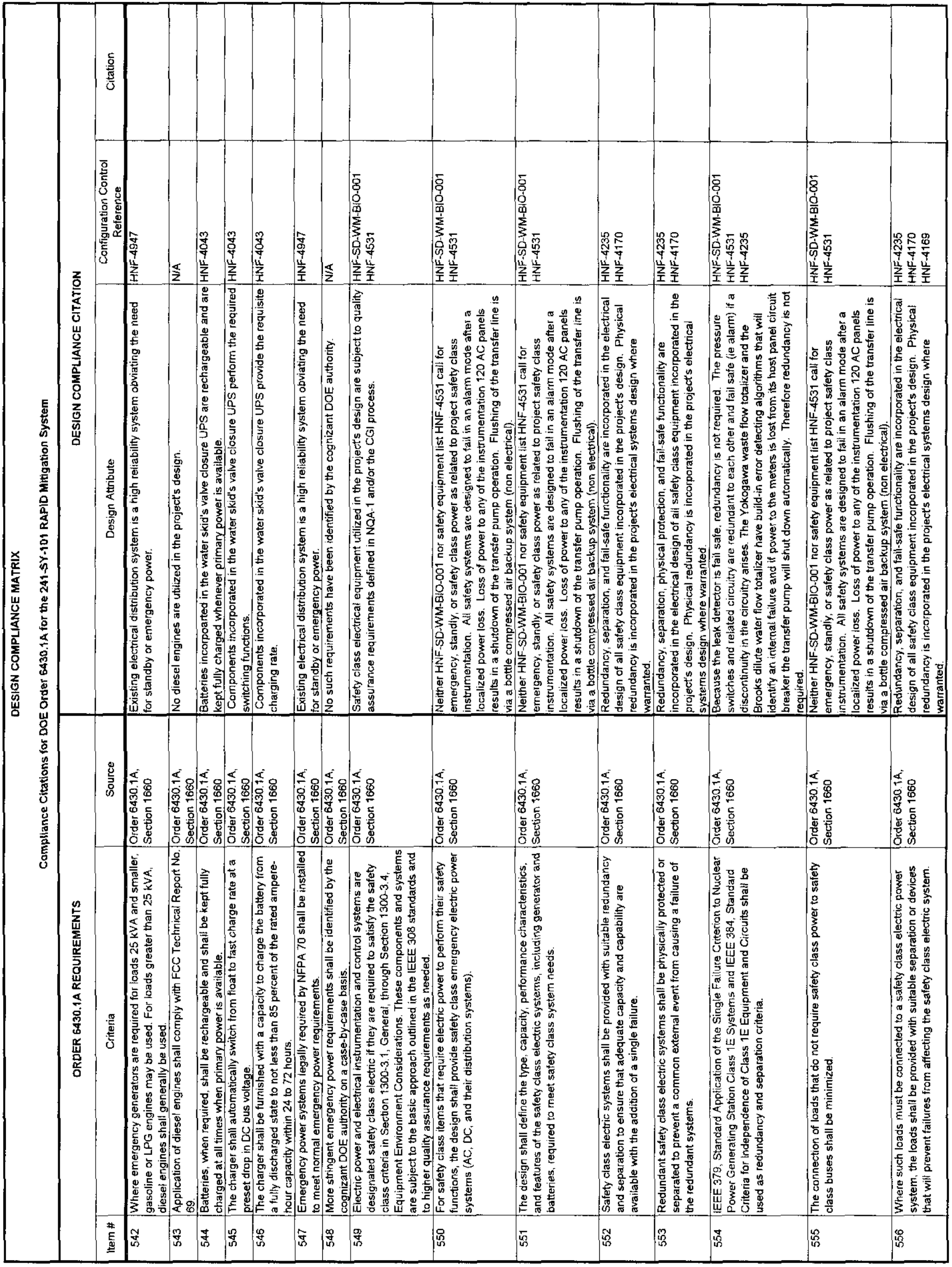




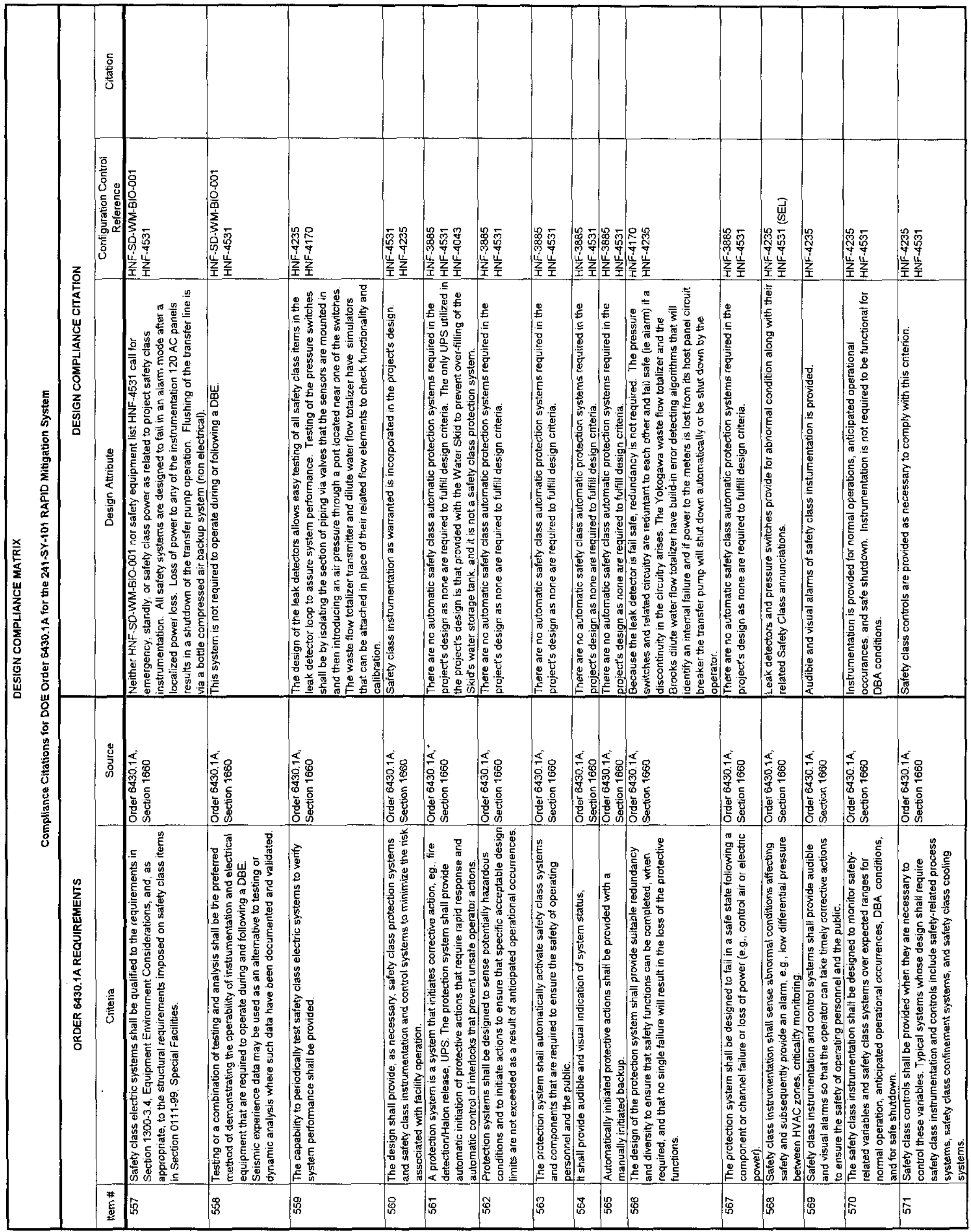




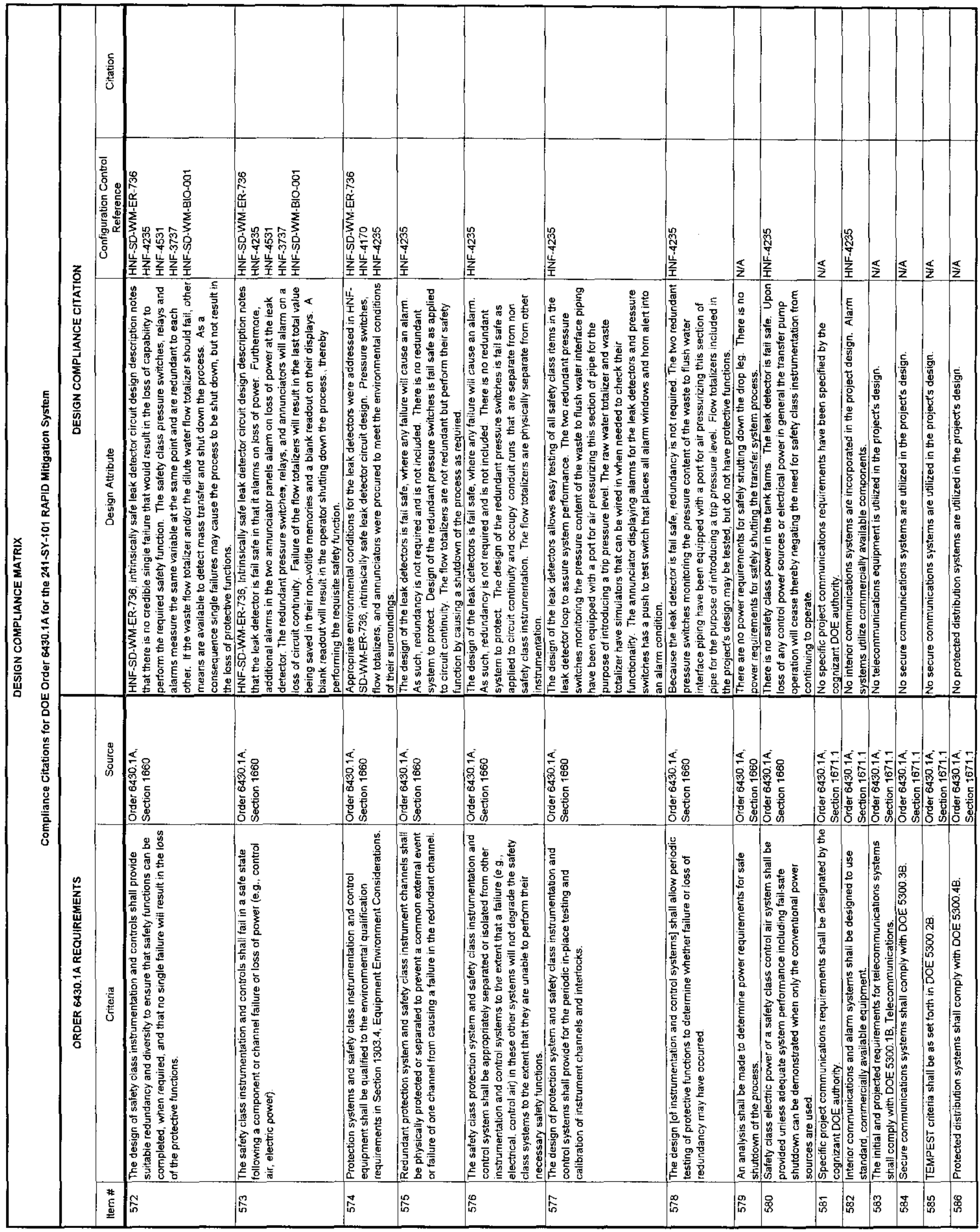




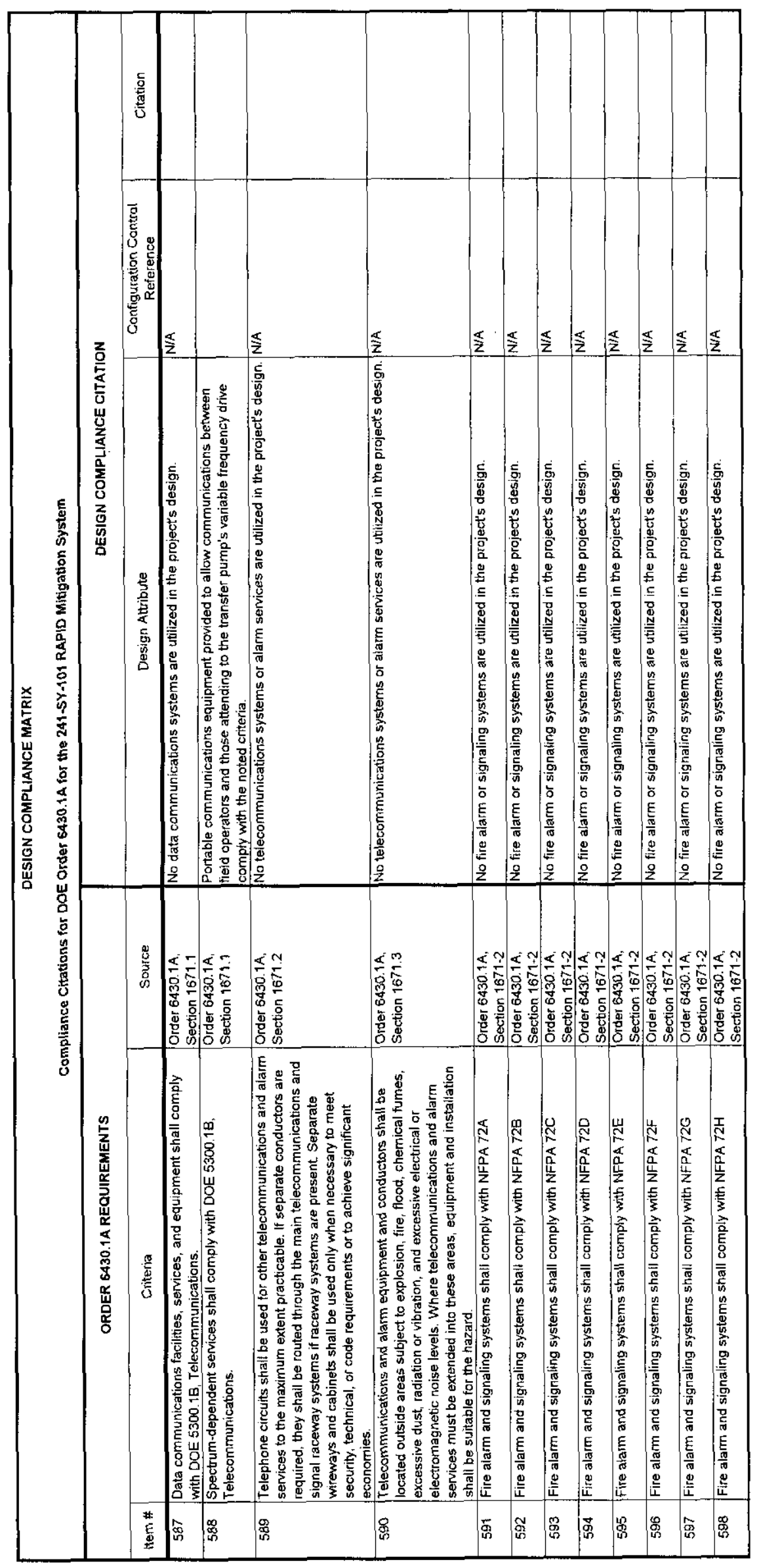




\subsection{CONCLUSIONS}

The design attributes noted in Section 3.0 fulfill all pertinent criteria contained in DOE Order 6430.1A as it relates to the 241-SY-101 RAPID Mitigation System, except as noted in this section. Criteria not fulfilled by the current state of the design are termed "open". Those "open" items where pending project activities will result in compliance with the Order are identified as "Pending activity" in Section 4.1 of this report. Those "open" items where technical basis exists to make a determination of "accept as is" are noted as such Section 4.1 of this report.

4.1 Specific criteria which are termed "open" are related to the following topics:

4.1.1 Pending activity - The applicability of wind missile loading of instrument enclosures is the subject of an interpretation to be issued by the LMHC chief engineer. To wit, that wind missile loading of instrument enclosures is not warranted as transfer is precluded by operational controls during high wind events, and that damage caused by wind-driven missiles during non-operational periods will be readily apparent to operators. This interpretation is applicable to criteria contained in matrix items 112 and 155. Issuance of this interpretation will be prior to initial operation of the RAPID Mitigation System.

4.1.2 Pending activity - Survey work to identify the as-built elevation of the PPP floor/transfer pump flange is a pending activity. The requirements contained in matrix items 193,194, and 195 will be complied with during performance of this activity. Performance of this work will be accomplished prior to initial operation of the RAPID Mitigation System.

4.1.3 Pending activity - The project's operational test procedure and issuance of the resulting operational test report are pending activities. Demonstrating compliance with the criteria contained in matrix items 250,299 , and 300 requires conclusion of this activity. Performance of this work will be accomplished prior to initial operation of the RAPID Mitigation System.

4.1.4 Accept as is - The general criteria contained in Section 1161-2 of the Order requiring that penetrations of confinement barriers have integrity equal to or greater than the barrier itself (matrix item 252) cannot be complied with. This results from the fact that the confinement barrier of the ASSD consists of a solid stainless steel wall. While the requisite penetration in this secondary confinement wall to service the installed leak detector has been demonstrated to be adequate to confine and contain leakage from primary confinement piping, it is impossible to meet or exceed the integrity of solid steel with any type of sealed penetration. This barrier meets or exceeds the 60 " w.c. requirement called out in the project's design criteria and assumed for the project's safety analysis. Therefore, it is recommended that the equipment be accepted as is.

4.1.5 Accept as is - The general criteria contained in Sections 1300-3.5 and 1300-3.6 of the Order (matrix item 305 and 314) are complied with in all respects save for the ability of the transfer line's encasement hose to be readily testable and be testable on a regular basis. The hose encasement 
cannot be easily tested. Test of the transfer line encasement hose requires removal and fitting of the hose with test fixtures. As the transfer line's primary hose will be contaminated after initial use, testing of the encasement line on a regular basis is not ALARA. Also, as the hose lifetime is one year, replacement of the transfer line hose assembly is assured after one year. Therefore, it is recommended that the equipment be accepted as is.

4.1.6 Pending activity - The preparation of a decontamination and decommissioning plan as required for compliance with the criterion specified in matrix item 379 is a pending activity which will be accomplished prior to the onset of decontamination and decommissioning activities.

4.1.7 Accept as is - The general criteria contained in Section 1660 of the Order related to the provision for emergency power to Safety Class 1 items, and for automatic switchover to emergency power and annunciation thereof (matrix items 531 and 535) are not complied with. The safety basis (HNF-3737 and the BIO, HNF-SD-WM-BIO-001) do not require this project to have emergency power for safety class items to perform their safety function. Therefore, it is recommended that the equipment be accepted as is.

4.2 It should be noted that the general criteria contained in Section 1323-4.2 of the Order requiring that traps in radioactive liquid waste lines shall be avoided is complied with. However, as noted in the design attribute referred to for this criterion (matrix item 387), while said traps are avoided to the maximum extent practicable, two potential traps are present in the Rapid System design. The first, installed in the PPP, acts as a seal loop to provide a means for draining confined liquid waste back to Tank SY-101 without providing a path for the escapement of tank dome space gases and vapors to the atmosphere. The second, the transfer line and encasement hose, is the subject of a letter from the LMHC chief engineer to the project's manager, dated $7 / 2 / 99$, which states that the presence of this trap is acceptable and unavoidable, due to the urgency associated with performance of the initial transfer.

4.3 The four pending activities recorded in Section 4.1 above will be tracked as open items on the project open item list. When they are completed, this document will be revised to show when and how they were completed.

4.4 The 1999 ORP contract document S/RID Section 7.1 requires compliance with portions of DOE Order 6430.1A. The following 7 items were extracted from S/RID Section 7.1 and repeated here, with compliance determined as part of the compliance matrix.

4.4.1 S/RID Section 7.1.6 - DOE Order 6430.1A, Section 0110-1.1.1 "Designs shall produce facilities that are straightforward and businesslike. Designs must respond to user needs but reflect a responsible use of public funds. Designs shall be defensible in terms of scope, cost, and appearance." The design of the RAPID Mitigation System meets this requirement, as indicated in compliance matrix items 2 and 3. 
4.4.2 S/RID Section 7.1.7 - DOE Order 6430.1A, Section 0109 - "This section lists the reference standards and guides cited in these criteria. The latest edition of standards and guides shall be used." Compliance matrix item 1 documents the project's general compliance with this criterion. However, as noted in compliance matrix 1, the 1994 version of the Unified Building Code was utilized in project design, in lieu of the latest version. The basis for this is as follows:

The 1996 PHMC contract specified the codes and standards to be followed; this includes DOE Order 5480.28, Natural Phenomenon Hazards Mitigation. Although this DOE Order has been superseded by DOE 420.1, DOE 420.1 has not been included in the contract, nor in the Tank Farms S/RID and therefore compliance with the DOE 5480.28 is still required. This Order in turn specifies the use of DOE-STD-1020, Natural Phenomenon Hazards Design and Evaluation Criteria. HNFPRO-097 (now LMH-PRO-097), Engineering Design and Evaluation, was developed to ensure compliance with DOE Order 5480.28 and DOESTD-1020. During the development of HNF-PRO-097, it was decided to use the then current version of the UBC, the 1994 version. The 1994 version of the UBC meets the requirements contained in DOE Order 5480.28 and DOE-STD-1020.

The 1997 version of the UBC (the latest edition) has several significant changes that do not match the requirements contained in DOE-STD-1020. To use this version of the UBC would require specific direction from DOE to resolve this discrepancy: specificaily, one contractual requirement (DOE Order 5480.28) requires the use of the 1994 version of the UBC, another (S/RID 7.1.7 to 6430.1A, Section 0109) would require use of the 1997 version of the UBC. Pending further guidance, the 1994 version has, and will continue, to be used even though it is not the latest version.

4.4.3 S/RID Section 7.1.7 - DOE Order 6430.1 A, Section 0140 [09] "Deviations from specified standards shall be identified and procedures established to ensure their control." No deviation from specified standards was required, except to add requirements in the case of SC items, or when existing standards are not totally appropriate for the item they are used on. These deviations from the standard may have included the waste transfer hose. This potential deviation has been identified and procedures established to ensure their control: the hose specification is HNF-4407 and is controlled and modified by Engineering Change Notice $(\mathrm{ECN})$ and its associated procedure. These changes are identified and controlled by a QA program developed and implemented in compliance with DOE 5700.6b and using the elements of DOE 4700.1 and ANSI/ANS NQA-1.

4.4.4 S/RID Section 7.2 - DOE Order 6430.1 A, Section 1300-6.1 - "Special facilities shall be designed to minimize personnel exposures to external and internal radiological hazards, provide adequate radiation monitoring and alarm systems, and provide adequate space for health physics 
activities." Compliance with this criterion is documented in matrix item 313 on page 25 of this document.

4.4.5 S/RID Section 7.2.2 - DOE Order 6430.1A, Section 0101-1 - "These criteria provide mandatory, minimally acceptable requirements for facility design. The predominant model building code in the region shall govern on issues not covered in these criteria." DOE Order 6430.1A was used for facility design as shown in the matrix table of this document. The UBC code was used when other building codes were not available, see LMHPRO-097, HNF-3885 and HNF-4252.

4.4.6 S/RID Section 7.2.2 - DOE Order 6430.1A, Section 0101-2 [03] - "The contractor and/or DOE organizations responsible for facility projects shall review these criteria early in the planning phase and at later phases during the project construction process to determine if any of these criteria are not applicable or are not appropriate." The contractor did review DOE Order 6430.1A early in the planning phase to determine if any of its criteria were not applicable or appropriate. The safety analysis for the project (HNF-3737) specifically calls out exemptions to the wind missile for the waste transfer hose. Other non-appropriate items implicit in the HNF-3737 and the BIO include not requiring:

- emergency power to Safety Class 1 items or switchover to emergency power when not required by the safety basis;

- confinement barriers that meet safety requirements but do not require exceeding stainless steel barrier integrity;

- wind missile loading of electrical equipment when there is appropriate controls already on hand to detect and test for a failure of the devices;

- $\quad$ and, a difficult to test $\mathrm{SC}$ hose encasement.

All these items noted above are within the authorization basis for the project and do not require further explicit exemption.

4.4.7 S/RID Section 7.2.2 - DOE Order 6430.1A, Section 0140 [07 and 08] "Wherever possible, design shall reflect experience gained on similar projects or similar types of construction." The project's design does reflect experience gained on similar project or similar types of construction. The team that brought together this design was well experienced with nuclear applications and construction. The Formal Design Review conducted provided an extra margin of safety and expertise for these applications.

4.5 The three accept-as-is determinations recorded in Section 4.1 above will not be pursued further. They are not required in order to meet the project's Authorization Basis. 